\title{
Diverse coral communities in mangrove habitats suggest a novel refuge from climate change
}

\author{
K. K. Yates ${ }^{1}$, C. S. Rogers ${ }^{2}$, J. J. Herlan ${ }^{2, *}$, G. R. Brooks ${ }^{3}$, N. A. Smiley ${ }^{1}$, and R. A. Larson ${ }^{3}$ \\ ${ }^{1}$ US Geological Survey, Coastal and Marine Science Center, St Petersburg, Florida 33701, USA \\ ${ }^{2}$ US Geological Survey, Southeast Ecological Science Center, St John, US Virgin Islands 00830, USA \\ ${ }^{3}$ Eckerd College, Galbraith Marine Science Laboratory, St. Petersburg, Florida 33711, USA \\ *now at: Universidad Católica del Norte, Larrondo 1281, Coquimbo, Chile
}

Correspondence to: K. K. Yates (kyates@usgs.gov)

Received: 20 February 2014 - Published in Biogeosciences Discuss.: 31 March 2014

Revised: 30 June 2014 - Accepted: 8 July 2014 - Published: 19 August 2014

\begin{abstract}
Risk analyses indicate that more than $90 \%$ of the world's reefs will be threatened by climate change and local anthropogenic impacts by the year 2030 under "business-asusual" climate scenarios. Increasing temperatures and solar radiation cause coral bleaching that has resulted in extensive coral mortality. Increasing carbon dioxide reduces seawater $\mathrm{pH}$, slows coral growth, and may cause loss of reef structure. Management strategies include establishment of marine protected areas with environmental conditions that promote reef resiliency. However, few resilient reefs have been identified, and resiliency factors are poorly defined.

Here we characterize the first natural, non-reef coral refuge from thermal stress and ocean acidification and identify resiliency factors for mangrove-coral habitats. We measured diurnal and seasonal variations in temperature, salinity, photosynthetically active radiation (PAR), and seawater chemistry; characterized substrate parameters; and examined water circulation patterns in mangrove communities where scleractinian corals are growing attached to and under mangrove prop roots in Hurricane Hole, St. John, US Virgin Islands. Additionally, we inventoried the coral species and quantified incidences of coral bleaching, mortality, and recovery for two major reef-building corals, Colpophyllia natans and Diploria labyrinthiformis, growing in mangroveshaded and exposed (unshaded) areas.

Over 30 species of scleractinian corals were growing in association with mangroves. Corals were thriving in low-light (more than $70 \%$ attenuation of incident PAR) from mangrove shading and at higher temperatures than nearby reef tract corals. A higher percentage of $C$. natans colonies were
\end{abstract}

living shaded by mangroves, and no shaded colonies were bleached. Fewer D. labyrinthiformis colonies were shaded by mangroves, however more unshaded colonies were bleached. A combination of substrate and habitat heterogeneity, proximity of different habitat types, hydrographic conditions, and biological influences on seawater chemistry generate chemical conditions that buffer against ocean acidification. This previously undocumented refuge for corals provides evidence for adaptation of coastal organisms and ecosystem transition due to recent climate change. Identifying and protecting other natural, non-reef coral refuges is critical for sustaining corals and other reef species into the future.

\section{Introduction}

Evidence that repeated coral bleaching events (Baker et al., 2008; Eakin et al., 2009; Fitt et al., 2001; Hoegh-Guldberg et al., 2007; Hoegh-Guldberg, 2011; Lesser, 2011) and ocean acidification (Fabricius et al., 2011; Kleypas and Yates, 2009; Kroeker et al., 2013, Silverman et al., 2009) will severely impede coral growth within the next few decades (Burke et al., 2011; van Hooidonk et al., 2014) has prompted an urgent search for coral reef systems that provide natural refuges from climate threats and efforts to identify mechanisms that could help reef organisms acclimatize to the changing climate. The complex interplay among climate, oceanographic, and biological factors that influences susceptibility and resilience of reefs has made identification and characterization of refuges challenging. Research is needed on how these 
factors interact and how they will affect the overall biodiversity, function, and transition of these ecosystems. Focus has been placed on identifying reefs with low exposure to or potential for adaptation to climate threats, and reduced local anthropogenic impacts (Keller et al., 2009; McClanahan et al., 2011; Mumby and Steneck, 2008; Salm et al., 2006; West and Salm, 2003). Recent studies have identified only a few reef systems, for example, in the western Indian Ocean (McClanahan et al., 2011), on the Great Barrier Reef (Berkelmans, 2002), and in shallow bays of Palau (van Woesik et al., 2012) that show resistance to elevated temperatures and less coral bleaching. Only one reef, in the Florida Keys, has been identified as a potential refuge from ocean acidification (Manzello et al., 2012). To our knowledge, no alternative (non-reef) natural habitats have ever been identified as potential climate change refuges for corals.

Mangrove communities, while often near coral reef ecosystems, are not thought of as having suitable conditions for coral recruitment and growth due to high sedimentation rates, lack of suitable substrate, and inadequate water quality. Therefore, no prior focus has been placed on identifying mangrove-coral habitats, the scientific literature contains few references to scleractinian corals growing in mangrove habitats (e.g. Macintyre et al., 2000; Rutzler et al., 2000), and no comprehensive surveys or multidisciplinary studies of these habitats have been performed.

In St. John, US Virgin Islands, over 30 species of scleractinian corals are growing on and under mangrove prop roots in small bays located along the perimeter of a large bay, Hurricane Hole, within the Virgin Islands Coral Reef National Monument (Table 1). Many are reef-building corals that survived a 2005 to 2006 bleaching and disease event that caused major losses of coral throughout the northeastern Caribbean (Miller et al., 2009). Qualitative surveys conducted in one bay in 1984 suggest that corals were present, but neither diverse nor abundant (Beets et al., 1986). We considered that an increase in the diversity and abundance of corals in mangrove communities since that time (Rogers and Herlan, 2012) could be a response to climate change.

Keppel et al. (2012) define refugia as "habitats that components of biodiversity retreat to, persist in and can potentially expand from under changing environmental conditions". The presence of such a remarkable abundance and diversity of coral species in the mangroves of St. John, and their largely intact condition in contrast to severe declines of corals on nearby reefs following bleaching and a major disease outbreak support the concept of this habitat as a refuge. This mangrove-coral habitat is characterized by heterogeneity in the physical environment that allows it to be out of equilibrium with open ocean conditions, resulting in differentiation of local physical, chemical, and biological attributes. This ecosystem serves as an example of how some mangrove habitats could provide alternative refuges for corals from climate threats, particularly increasing seawater temperature, high levels of solar radiation, and decreasing $\mathrm{pH}$.
Table 1. Species list of corals living in mangroves.

\begin{tabular}{|c|c|c|c|}
\hline Coral species & $\begin{array}{l}\text { Princess } \\
\text { Bay }\end{array}$ & $\begin{array}{l}\text { Otter } \\
\text { Creek }\end{array}$ & $\begin{array}{l}\text { Water } \\
\text { Creek }\end{array}$ \\
\hline Stephanocoenia intersepta & $x$ & $x$ & $x$ \\
\hline Acropora palmata & & & $x$ \\
\hline Agaricia agaricites & $\times$ & $\times$ & $x$ \\
\hline Agaricia spp. & & $x$ & $x$ \\
\hline Siderastrea siderea & $x$ & $x$ & $x$ \\
\hline Siderastrea radians & $\times$ & $x$ & $x$ \\
\hline Porites astreoides & $\times$ & $\times$ & $x$ \\
\hline Porites porites & $\times$ & $\times$ & $x$ \\
\hline Porites furcata & $\times$ & $\times$ & $x$ \\
\hline Porites divaricata & $\times$ & & \\
\hline Favia fragum & $\times$ & $x$ & $x$ \\
\hline Diploria labyrinthiformis & $\times$ & $x$ & $x$ \\
\hline Pseudodiploria clivosa & & $x$ & $x$ \\
\hline Pseudodiploria strigosa & $\times$ & $x$ & $x$ \\
\hline Manicina areolata & $x$ & $x$ & $x$ \\
\hline Colpophyllia natans & $x$ & $x$ & $x$ \\
\hline Colpophyllia amaranthus & & $x$ & \\
\hline Cladocora arbuscula & $\times$ & & \\
\hline Orbicella annularis & $\times$ & $\times$ & \\
\hline Orbicella faveolata & $x$ & $x$ & $x$ \\
\hline Orbicella franksi & & $x$ & $x$ \\
\hline Montastraea cavernosa & & $x$ & $x$ \\
\hline Solenastrea bournoni & & $x$ & \\
\hline Phyllangia americana & & $x$ & \\
\hline Oculina diffusa & $\times$ & $x$ & \\
\hline Meandrina meandrites & & $x$ & $x$ \\
\hline Dichocoenia stokesi & & & $x$ \\
\hline Dendrogyra cylindrus & & $x$ & $x$ \\
\hline Scolymia cubensis & $\times$ & $x$ & $x$ \\
\hline Scolymia lacera & & $x$ & \\
\hline Mycetophyllia spp. & & $x$ & $x$ \\
\hline Eusmilia fastigiata & & $x$ & $x$ \\
\hline Tubastrea aurea & & $x$ & $x$ \\
\hline Millepora spp. & $\times$ & $x$ & $x$ \\
\hline Totals & 19 & 30 & 26 \\
\hline
\end{tabular}

We identified and quantified physical, chemical, and biological resiliency factors in mangrove communities with corals in Hurricane Hole, St. John, US Virgin Islands. We present a list of resiliency factors to help guide identification of other alternative refuges for reef-building corals.

\section{Methods}

Physical, chemical, and biological attributes were characterized in three small, adjacent bays in Hurricane Hole including Water Creek, Otter Creek, and Princess Bay in November 2010, July 2011, and July 2012 (Fig. 1). In each bay, we measured diurnal and seasonal variations in temperature, salinity, photosynthetically active radiation (PAR), and seawater chemistry [total alkalinity $\left(A_{\mathrm{T}}\right)$, dissolved inorganic 


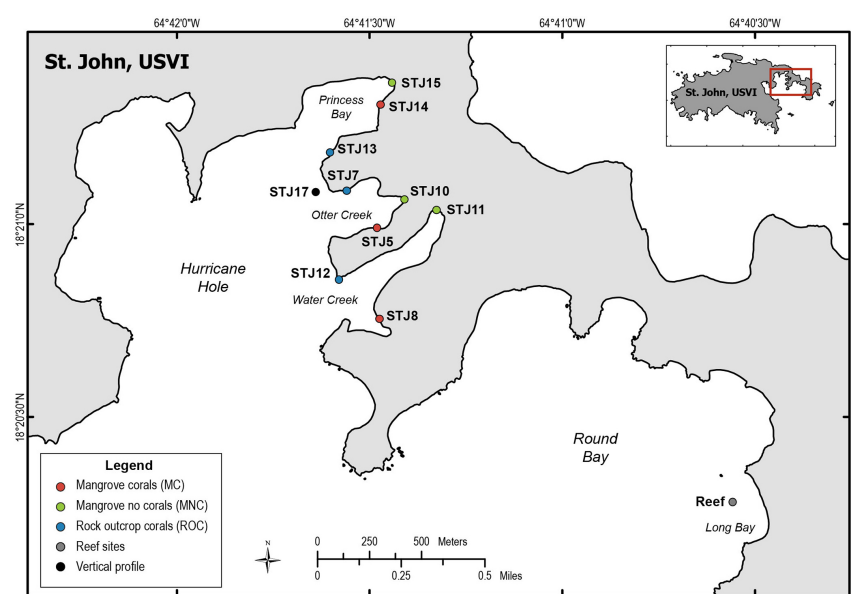

Figure 1. Study sites (STJ\#) in Hurricane Hole. MC are mangroves with corals growing on and near mangrove prop roots and shaded by the mangrove canopy, MNC are mangroves with no corals growing in association with them, ROC are rock outcrops with live corals and no shading from mangroves.

carbon $\left(C_{\mathrm{T}}\right), \mathrm{pH}_{\mathrm{T}}\left(\mathrm{pH}\right.$ on the total $\mathrm{H}^{+}$scale), dissolved oxygen (DO), and nutrients]. We characterized substrate parameters and examined water circulation patterns associated with inner-bay mangrove communities with no corals (MNC sites), nearby mid- to outer-bay mangrove communities with corals growing on and under prop roots (MC sites), and rock outcrops with unshaded corals (ROC sites) in all three bays. Corals at these sites were growing near the coastline in shallow water ranging from 1.2 to $2.0 \mathrm{~m}$ water depth. Additionally, we inventoried coral species in all three bays, and quantified incidences of coral bleaching, mortality, and recovery for two major reef-building corals, Colpophyllia natans and Diploria labyrinthiformis, growing in mangrove-shaded and exposed (unshaded) areas in the bays with the highest coral diversity (Otter Creek and Water Creek). Logistics prevented concurrent collection of similar data from reefs around St. John. However, we previously collected limited data from four sites on a nearby reef in Long Bay (approximately $2 \mathrm{~km}$ from the nearest mangrove coral study site and $6.3 \mathrm{~m}$ water depth, Fig. 1) from 16 July to 22 August 2004. The reef sites were characterized by scattered coral colonies of Orbicella annularis complex, Montastraea cavernosa. Porites porites, Porites astreoides, Agaricia agaricites, Favia fragum, Diploria labyrinthiformis, and the hydrocoral Millepora alcicornis growing among sea fans, other gorgonians, sponges, turf algae, macroalgae and coral rubble. All seawater chemistry data from Hurricane Hole and Long Bay reef sites were collected near the seafloor (less than $0.5 \mathrm{~m}$ from the bottom). Additionally, we collected vertical profile data of carbonate system parameters over a coral habitat at $6.5 \mathrm{~m}$ water depth near the mouth of Otter Creek (Fig. 1) at 07:00 AST on 19 July 2011. Profile data were collected at 1.5, 3.0, 4.6, and $6.0 \mathrm{~m}$ depth.

\subsection{Seawater chemistry}

Seawater was collected for $A_{\mathrm{T}}, C_{\mathrm{T}}$, and $\mathrm{pH}_{\mathrm{T}}$ analyses from each site every $4 \mathrm{~h}(n=7)$ throughout $24 \mathrm{~h}$ periods in November 2010, July 2011, and July 2012. Measurements were made every $4 \mathrm{~h}$ for 3 consecutive days $(n=19)$ in Otter Creek during July 2012. No DO data were collected in Water Creek during July 2012 due to DO sensor failure. Twenty percent of $\mathrm{pH}$ values (47 of 225) were calculated from $A_{\mathrm{T}}$ and $C_{\mathrm{T}}$. A peristaltic pump was used to pump seawater from less than $0.5 \mathrm{~m}$ above the seafloor through a $0.45 \mu \mathrm{m}$ filter into $500 \mathrm{ml}$ borosilicate glass bottles. Samples for $A_{\mathrm{T}}$ and $C_{\mathrm{T}}$ were preserved by adding $100 \mu \mathrm{L}$ saturated $\mathrm{HgCL}_{2}$ solution. Bottles were positive-pressure sealed with ground glass stoppers coated with Apiezon grease. Seawater samples for $\mathrm{pH}_{\mathrm{T}}$ were collected from the same peristaltic pump and filtered into $30 \mathrm{~mL}$ glass optical cells, and were analyzed within $1 \mathrm{~h}$ of collection. Samples were analyzed for $A_{\mathrm{T}}\left( \pm 1 \mu \mathrm{mol} \mathrm{kg}{ }^{-1}\right)$ using spectrophotometric methods of Yao and Byrne (1998) with an Ocean Optics USB2000 spectrometer and bromocresol purple indicator dye, for $C_{\mathrm{T}}\left( \pm 3 \mu \mathrm{mol} \mathrm{kg}{ }^{-1}\right)$ using a UIC carbon coulometer model CM5014 and CM5130 acidification module using methods of Dickson et al. (2007) and for $\mathrm{pH}_{\mathrm{T}}( \pm 0.005)$ via spectrophotometric methods of Zhang and Byrne with an Ocean Optics USB2000 spectrometer and thymol blue indicator dye. Dissolved oxygen $\left( \pm 0.1 \mathrm{mg} \mathrm{l}^{-1}\right)$, temperature $\left( \pm 0.01^{\circ} \mathrm{C}\right)$, and salinity $( \pm 0.01)$ were measured using a YSI multimeter calibrated daily. Certified reference materials (CRM) for $A_{\mathrm{T}}$ and $C_{\mathrm{T}}$ analyses were from the Marine Physical Laboratory of Scripps Institution of Oceanography (A. Dickson). Duplicate or triplicate analyses were performed on at least $10 \%$ of samples.

Seawater from Long Bay reef was also collected and analyzed for $A_{\mathrm{T}}$ and $C_{\mathrm{T}}$ using the same methods as in Hurricane Hole. $\mathrm{pH}_{\mathrm{T}}$ was calculated from $A_{\mathrm{T}}$ and $C_{\mathrm{T}}$ using the carbonate speciation program CO2sys (Pierrot et al., 2006). Dissolved oxygen $\left( \pm 0.1 \mathrm{mg} \mathrm{l}^{-1}\right)$, temperature $\left( \pm 0.01^{\circ} \mathrm{C}\right)$, and salinity $( \pm 0.01)$ were measured using a flow-through analytical system and methods of Yates and Halley (2003). These data were collected at 07:00 $(n=7)$ or 11:00 $(n=3)$.

Vertical profile data were collected by attaching a weighted peristaltic sampling tube (marked with depth increments) to the YSI multimeter and lowering the collection apparatus to depth along a guide line attached to a buoy at the surface and a weight at the seafloor. Samples and measurements for $A_{\mathrm{T}}, C_{\mathrm{T}}, \mathrm{pH}_{\mathrm{T}}, \mathrm{DO}$, salinity, and temperature were collected and analyzed using the same methods as described for Hurricane Hole analyses. Carbonate system parameters for all study sites including aragonite mineral saturation state $\left(\Omega_{\mathrm{A}}\right)$ and $p \mathrm{CO}_{2}$ were calculated from $A_{\mathrm{T}}, \mathrm{pH}_{\mathrm{T}}$ (or $A_{\mathrm{T}}$ and $C_{\mathrm{T}}$ for Long Bay reef samples), temperature, and salinity measurements using the carbonate speciation program CO2sys (Pierrot et al., 2006) with dissociation constants K1 and K2 from Merbach et al. (1973) refit by Dickson and Millero (1987), $\mathrm{KSO}_{4}$ from Dickson (1990), 
and using the total $\mathrm{pH}$ scale $\left(\mathrm{pH}_{\mathrm{T}}\right)$. Correlation analysis of salinity-normalized total alkalinity $\left(\mathrm{nA}_{\mathrm{T}}\right)$ and dissolved inorganic carbon $\left(\mathrm{nC}_{\mathrm{T}}\right)$ was performed on Hurricane Hole data using methods of Suzuki and Kawahata (2003) to examine heterogeneity of chemical and biological processes.

Seawater samples were collected for the measurement of total nitrogen and phosphate in November 2010 and July 2011. In November 2010, nutrient samples $(n=58)$ were collected in transects spanning the innermost reaches to the mouth of all three bays. During July 2011, water samples were collected every $4 \mathrm{~h}$ throughout $24 \mathrm{~h}$ time periods at every sample site in all three bays. Water samples $(20 \mathrm{~mL})$ were filtered through $0.22 \mu \mathrm{m}$ pore size Millepore Sterivex filters rinsed with two volumes of sample water. Samples were stored in $20 \mathrm{~mL}$ acid-washed polypropylene scintillation vials at $0^{\circ} \mathrm{C}$ until time of analysis. Nutrient samples were analyzed at the NOAA Atlantic Oceanographic and Meteorological Laboratory in Miami, FL.

\subsection{Sediment samples}

Bulk surface sediment samples (approximately $2 \mathrm{~kg}$ wet weight) were collected via grab-sampling from the seafloor (approximately $1.2 \mathrm{~m}$ water depth) at each study site in each bay (Fig. 1). Wet samples were dehydrated to remove water and salts within $6 \mathrm{~h}$ of collection by rinsing with $70 \%$ isopropyl alcohol, allowing samples to settle, decanting the alcohol, and repeating this process two additional times. Samples were then allowed to air dry prior to analysis for grain size and composition. Grain size was measured via settlingtube for sand-sized fractions (Gibbs, 1974), and pipette for mud-sized fractions (Folk, 1965). Calcium carbonate content was determined by the acid leaching method (Milliman, 1974). Total organic matter (TOM) was measured by loss on ignition (LOI) at $550^{\circ} \mathrm{C}$ for $>2.5 \mathrm{~h}$ (Dean, 1974). Mineralogic composition was measured by XRD on a Bruker D-8 advanced system using cobalt radiation at the University of Georgia, Department of Geology.

\subsection{Coral surveys}

A list of coral species growing in Princess Bay, Otter Creek, and Water Creek was compiled based on over 100 surveys conducted by snorkeling the perimeter of each bay and identifying all live coral colonies growing from the shoreline to a depth of approximately $6 \mathrm{~m}$ (Rogers and Herlan, 2012). Minor coral bleaching was observed in July 2010 with more severe bleaching in August through October 2010. From November 2010 to January 2011, a complete census of colonies of Diploria labyrinthiformis and Colpophyllia natans (the most abundant framework-building corals in Hurricane Hole) was conducted in Otter Creek and Water Creek. The census included colonies growing in the mangroves and on the nearby substrate that sloped to the sandy bottom in each of the bays. Coral depths ranged from near the surface
Table 2. Location of HOBO temperature loggers in Hurricane Hole.

\begin{tabular}{llll}
\hline Logger ID & Location & Latitude (DD) & Longitude (DD) \\
\hline 1208639 & Otter Creek mid-bay & 18.34965 & -64.69215 \\
9712498 & Princess Bay mid-bay & 18.35562 & -64.69455 \\
9712499 & Otter Creek mid-bay & 18.35160 & -64.69240 \\
9712501 & Water Creek mid-bay & 18.34777 & -64.69076 \\
9712501 & Water Creek mid-bay & 18.34773 & -64.69072 \\
9712503 & Water Creek inner-bay & 18.34963 & -64.68951 \\
9712511 & Otter Creek inner-bay & 18.35119 & -64.69111 \\
9712522 & Otter Creek outer-bay & 18.34950 & -64.69243 \\
9712524 & Otter Creek inner-bay & 18.35008 & -64.69069 \\
9712525 & Water Creek mid-bay & 18.34850 & -64.69146 \\
9712534 & Water Creek inner-bay & 18.35066 & -64.68871 \\
9712537 & Water Creek outer-bay & 18.34596 & -64.69165 \\
9712538 & Princess Bay outer-bay & 18.35328 & -64.69333 \\
9712540 & Otter Creek inner-bay & 18.35107 & -64.69013 \\
9712541 & Water Creek mid-bay & 18.34890 & -64.69048 \\
9712545 & Princess Bay inner-bay & 18.35615 & -64.69069 \\
9712546 & Water Creek mid-bay & 18.34755 & -64.68956 \\
9712547 & Otter Creek inner-bay & 18.35198 & -64.69169 \\
\hline
\end{tabular}

to about 6 meters. Each coral was photographed and examined for condition (e.g., bleached or unbleached) and exposure (shaded or unshaded). A coral was considered shaded if it grew directly under mangroves or within a few meters of them where it received shading for at least a portion of each day. Subsets of these colonies in Otter Creek were reexamined in May 2011 to document recovery and mortality. Fisher's exact tests performed in SAS 9.2 were used to compare the response of shaded and unshaded coral colonies for each species. Additionally, we calculated the log-odds ratios and confidence intervals to determine the effect of shading on coral bleaching for both species combined.

\subsection{Temperature and PAR measurements}

Temperature measurements were collected every $2 \mathrm{~h}$ during 2010 and 2011 using HOBO Pendant data loggers at 18 locations in Hurricane Hole (Table 2). Loggers were placed near mangrove and coral habitats at inner-, mid-, and outerbay locations. Daily averages were generated from all loggers. Temperature data from long-term monitoring transects were collected every $2 \mathrm{~h}$ from loggers at reef depth on the fore-reef slope area of six reefs around St. John during 2005 and 2010 by the National Park Service (Miller et al., 2009; National Park Service 2012). These data were used to calculate daily means at each site and averaged among sites to generate daily averages for the long-term reef transects. Photosynthetically active radiation (PAR) was measured every 15 min (15-minute averages) at study sites in Otter Creek and Water Creek approximately $20 \mathrm{~cm}$ above the seafloor using LI-COR $4 \pi$ sensors and approximately $3 \mathrm{~m}$ above sea level and above the mangrove canopy using LI-COR $2 \pi$ sensors coupled with LiCor 1000 or LI-COR 1400 data loggers. PAR sensors were placed on the seafloor under the mangrove canopy and outside of the mangrove canopy at MNC and MC 
Table 3. Grain size of surface sediments.

\begin{tabular}{cccccccccc}
\hline $\begin{array}{c}\text { Sample } \\
\text { location }\end{array}$ & \% Gravel & \% Sand & \% Silt & \% Clay & \% Mud & Mean $\Phi^{1}$ & \% Carbonate & \% TOM TOM $^{2}$ & $\begin{array}{c}\text { \% Insoluble } \\
\text { residue }\end{array}$ \\
\hline STJ5 & 71.0 & 20.7 & 4.7 & 3.5 & 8.2 & -0.4 & 93.9 & 2.2 & 3.9 \\
STJ7 & 14.9 & 80.6 & 3.7 & 0.8 & 4.5 & 1.0 & 73.8 & 0.3 & 25.9 \\
STJ8 & 58.2 & 25.8 & 11.6 & 4.4 & 16.0 & 0.4 & 69.7 & 7.1 & 23.2 \\
STJ10 & 15.0 & 27.7 & 44.2 & 13.1 & 57.3 & 3.5 & 54.6 & 11.9 & 33.5 \\
STJ11 & 2.7 & 81.7 & 13.6 & 2.0 & 15.6 & 1.9 & 20.0 & 1.0 & 79.0 \\
STJ12 & 9.2 & 88.2 & 1.0 & 1.6 & 2.6 & 1.3 & 96.8 & 0.1 & 3.1 \\
STJ13 & 24.2 & 52.4 & 17.6 & 5.9 & 23.5 & 2.0 & 82.8 & 1.4 & 15.8 \\
STJ14 & 38.0 & 31.2 & 27.0 & 3.7 & 30.8 & 1.6 & 74.9 & 6.2 & 18.9 \\
STJ15 & 0.5 & 35.0 & 61.8 & 2.6 & 64.5 & 4.3 & 11.7 & 2.9 & 85.4 \\
\hline
\end{tabular}

$1-\log _{2}$ of the grain diameter in $\mathrm{mm},{ }^{2}$ total organic matter from loss on ignition. See Fig. 1 for sample locations.

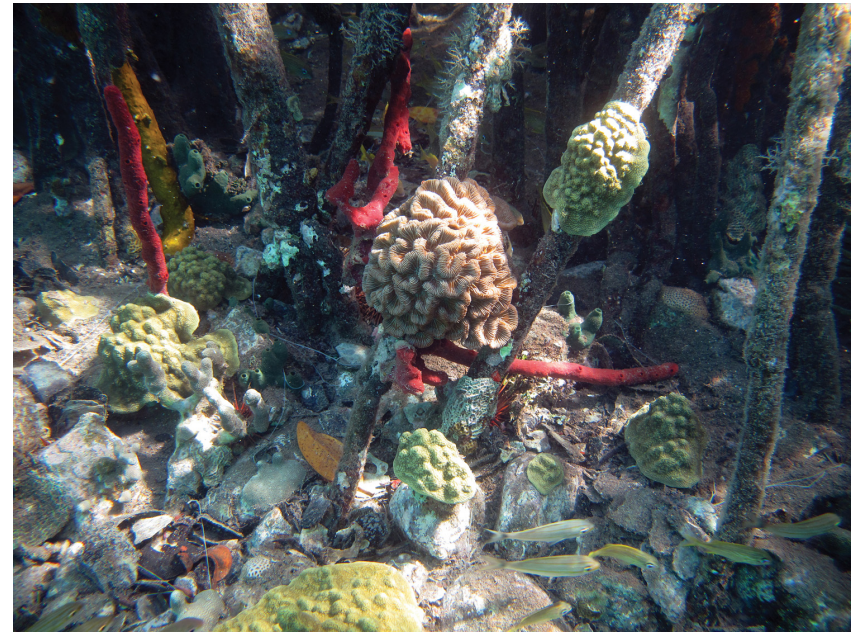

Figure 2. Corals growing under a mangrove canopy and attached to mangrove prop roots including a colony of Colpophyllia natans (center of photo).

sites, on the seafloor at unshaded ROC sites, and above the mangrove canopy at MC and MNC sites.

\section{Results and discussion}

\subsection{Heterogeneity of the physical environment}

Heterogeneity in the physical environment provides for semiisolation of coastal water masses from open ocean water enabling local differentiation of physical, chemical, and biological attributes of coastal ecosystems. The potential for a refuge to sustain characteristics that promote climate change resiliency is, in part, dependent upon the ability of the system to remain out of equilibrium with open ocean chemical conditions.

The bays in Hurricane Hole range in area from 0.06 to $0.11 \mathrm{~km}^{2}$, have small watersheds ranging in size from 0.11 to $0.43 \mathrm{~km}^{2}$, are surrounded by steeply sloped, rocky hillsides, and have a narrow (up to approximately $10 \mathrm{~m}$ ) fringe of red mangroves (Rhizophora mangle). Bedrock is exposed as cliffs and outcrops along the coast and consists of igneous and metamorphic rocks including Cretaceous basalt, andesite, and keratophyre (Rankin, 1998). Carbonate sediments on St. John are in situ marine biogenic carbonates. There is no permanent source of freshwater inflow to any of the bays, nutrient concentrations are low, water clarity is generally high, and tidal range is low $(<0.25 \mathrm{~m})$. The inner areas of the bays are very shallow, less than $2 \mathrm{~m}$, and well protected from high winds and seas. The mangrove fringe is thickest in the inner bays. Prop roots support abundant communities of reef and mangrove organisms including crustose coralline algae, and are surrounded by communities of intermediate density seagrass (Thalassia testudinum) and calcareous algae including Halimeda spp. and Penicillus spp. Very few corals are growing near inner-bay mangroves. Grain size analyses showed that sediments in the inner bays are primarily fine-grained ranging from 16 to $65 \%$ mud-sized fractions (Table 3).

Mid- to outer-bay areas are characterized by narrower mangrove fringes and shallow $(<1 \mathrm{~m})$ water depths immediately adjacent to the shoreline that slopes steeply to 5 to $10 \mathrm{~m}$ just beyond the mangrove canopy. The mangrove prop roots support sponges, crustose coralline algae, numerous scleractinian corals and other organisms (Fig. 2). The outer bays are infrequently exposed to storm waves that remove finegrained sediments, and sediments consist primarily of 69 to $96 \%$ sand and gravel with occasional occurrences of large boulders (Table 3). Corals are growing attached directly to prop roots and to hard substrates under roots. Near the entrance to the bays, there are rock outcrops with few or no mangroves nearby. These sites have primarily hard bottom substrate with small pockets of coarse-grained sediments, corals growing directly on the hard bottom, very sparse occurrences of calcareous algae, and little seagrass growing nearby. 


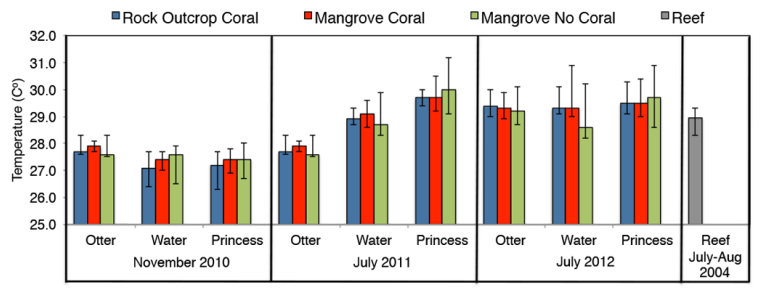

b.

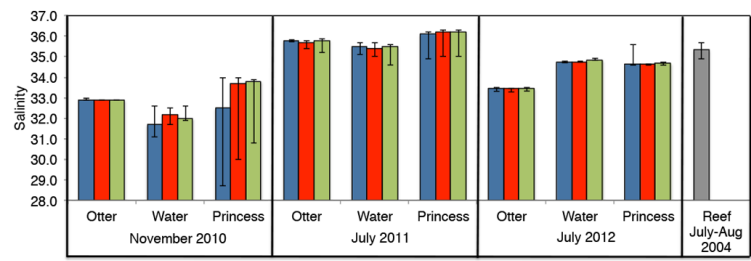

C.

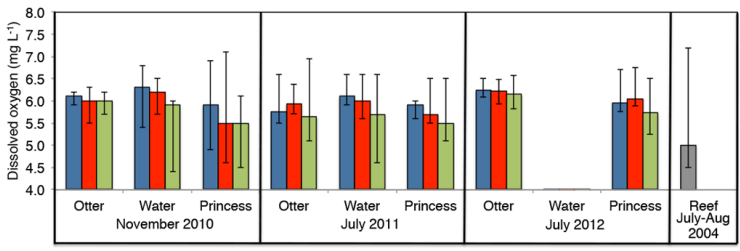

d.

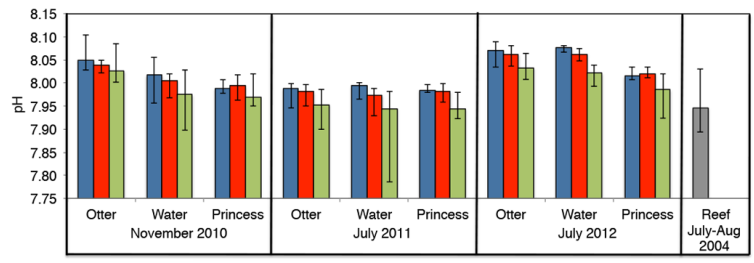

e.

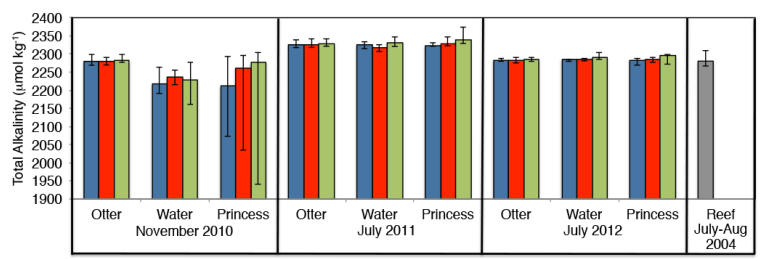

f.

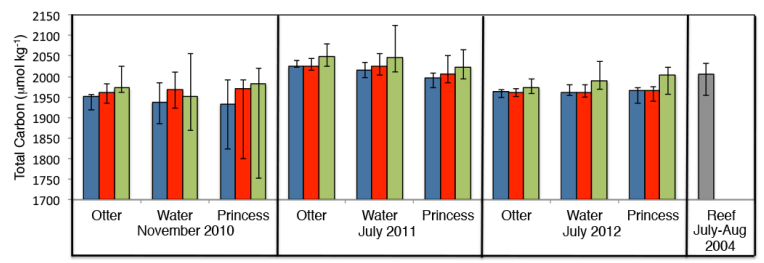

g.

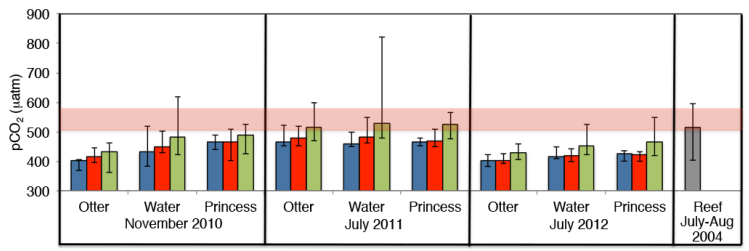

h.

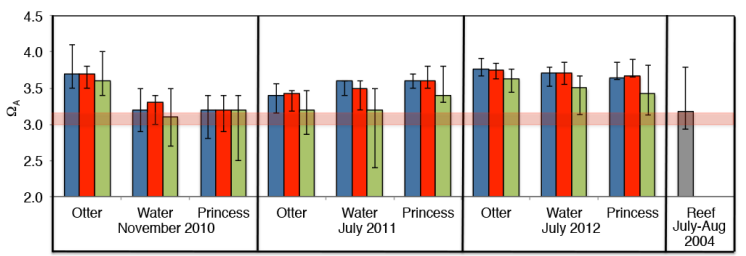

Figure 3. Chemical and physical parameters. Median and range for chemical and physical parameters in Hurricane Hole bays during November 2010, July 2011, and July 2012 and for Long Bay reef during July and August $2004(n=10)$. Measurements were made every $4 \mathrm{~h}$ throughout a diurnal cycle $(n=7)$ at each study site during November 2010 and July 2011, and July 2012, and for 3 consecutive days $(n=19)$ in Otter Creek during July 2012. Measurements at Long Bay reef were made at 07:00 and 11:00 ( $n=7$ and 3, respectively). No DO data were collected in Water Creek during July 2012 due to DO sensor failure. Red shaded areas (3g and 3h) show reported ranges for $p \mathrm{CO}_{2}$ and $\Omega_{\mathrm{A}}$ thresholds for carbonate calcification and dissolution. Data and latitude/longitude of study sites are available at http://doi.pangaea.de/10.1594/PANGAEA.825752.

\subsection{Chemical heterogeneity}

Heterogeneity in the physical environment and benthic community structure creates chemical micro-climates that can affect adjacent habitats. Variations in chemical trends were observed at the sub-kilometer scale in each bay and in association with specific habitat types (Fig. 3). MNC sites showed the lowest $\mathrm{DO}, \mathrm{pH}_{\mathrm{T}}$, and $\Omega_{\mathrm{A}}$ (with the exception of Otter Creek in November 2010) and highest $p \mathrm{CO}_{2}, A_{\mathrm{T}}$, and $C_{\mathrm{T}}$. Salinity and $A_{\mathrm{T}}$ showed the highest range in Water Creek and Princess Bay during Tropical Storm Tomás in November 2010. These bays have larger watersheds than Otter Creek and are more heav- ily influenced by terrestrial runoff during rain events. MC and ROC sites showed higher $\mathrm{DO}, \mathrm{pH}_{\mathrm{T}}$, and $\Omega_{\mathrm{A}}$, and lower $p \mathrm{CO}_{2}, A_{\mathrm{T}}$, and $C_{\mathrm{T}}$ than MNC sites. Diurnal variability was also observed at each study site. Lowest $\Omega_{\mathrm{A}}$, $\mathrm{pH}_{\mathrm{T}}$, temperature and $\mathrm{DO}$, and highest $C_{\mathrm{T}}, p \mathrm{CO}_{2}$, and $T_{\mathrm{A}}$ generally occurred in early morning and were reflected in our 07:00 measurements (see http://doi.pangaea.de/10. 1594/PANGAEA.825752). Vertical profile data showed water column heterogeneity with considerable differences in $\Omega_{\mathrm{A}}(\Delta 0.34), \mathrm{pH}(\Delta 0.04), p \mathrm{CO}_{2}(\Delta 40 \mu \mathrm{atm}), \mathrm{TA}(\Delta$ $\left.45.3 \mu \mathrm{mol} \mathrm{kg}^{-1}\right)$, and $C_{\mathrm{T}}\left(\Delta 20.9 \mu \mathrm{mol} \mathrm{kg}{ }^{-1}\right)$ between surface and bottom water (Fig. 4, Table 4), indicating that sur- 
face water measurements do not reflect bottom water conditions. Average total nitrate and phosphate values (data at http: //doi.pangaea.de/10.1594/PANGAEA.825752) were near the limits of resolution for $A_{\mathrm{T}}$ measurements and, therefore, were not included in calculation of carbonate system parameters from $A_{\mathrm{T}}$ and $\mathrm{pH}_{\mathrm{T}}$ measurements.

Calcification/dissolution thresholds are the levels of $\Omega_{\mathrm{A}}$ below which (and $p \mathrm{CO}_{2}$ levels above which) net dissolution of carbonate sediments exceeds calcification rates as determined by in situ, mesocosm, and modeling studies of coral reef ecosystems. Aragonite saturation states fell considerably lower than threshold ranges of 3.0 to 3.2 and/or $p \mathrm{CO}_{2}$ exceeded thresholds of 504 to $584 \mu$ atm (Langdon et al., 2003; Silverman et al., 2009; Yamamoto et al., 2012; Yates and Halley, 2006) at all MNC study sites in Princess Bay and Water Creek during November 2010 and July 2011 and 2012. Thresholds at the Otter Creek MNC site were exceeded only during July 2011. Aragonite saturation states at all MC and ROC sites remained above threshold levels except in Water Creek and Princess Bay during the November 2010 tropical storm; $p \mathrm{CO}_{2}$ values were considerably lower at all $\mathrm{MC}$ and ROC sites than at MNC sites (Fig. 3g and h).

Long Bay reef data were collected only at 07:00 and 11:00 AST (Fig. 3, Table 5). Therefore, only minimum $\Omega_{\mathrm{A}}$, $\mathrm{pH}$, temperature and DO, and maximum TA, $C_{\mathrm{T}}$, and $p \mathrm{CO}_{2}$ values are comparable to Hurricane Hole data. Median data for reef parameters may be biased toward lower or higher values because they do not reflect full diurnal cycle conditions; comparison of reef data to Hurricane Hole excludes November 2010 data that reflect tropical storm conditions. Minimum reef $\Omega_{\mathrm{A}}(2.93)$ was considerably lower than any other coral site in Hurricane Hole and lower than the reported range of dissolution thresholds. The lowest $\Omega_{\mathrm{A}}$ (3.18) at Hurricane Hole coral sites occurred in Otter Creek during July 2011, and it was the only coral site that showed an $\Omega_{\mathrm{A}}$ within the carbonate dissolution threshold range. All median and maximum values from Hurricane Hole coral sites in July 2011 and July 2012 were above threshold ranges, and maximum values reached 4.2. Minimum $\mathrm{pH}$ at the reef was 7.894, and was lower than the lowest $\mathrm{pH}$ (7.950, also in Otter Creek during July 2011) recorded for any coral site in Hurricane Hole. Maximum $p \mathrm{CO}_{2}$ values at the reef (626 $\mu$ atm) were higher than any coral site in Hurricane Hole (maximum $=550 \mu \mathrm{atm}$ in Water Creek, July 2011) and were above the reported dissolution threshold range. Our data indicate that $\Omega_{\mathrm{A}}$ was not consistently elevated at mangrove coral sites relative to the reef. However, minimum $\Omega_{\mathrm{A}}$ at mangrove coral sites was not as low as reef values, and, in most locations, remained above thresholds for carbonate dissolution unlike reef values.

X-ray diffraction analyses of sediments in Hurricane Hole indicated all MNC sites have the lowest percentages of carbonate sediments (12 to $55 \%$ ) and no high-magnesium calcite (high-Mg calcite, the most soluble phase of calcium carbonate) in two of the three bays (Princess Bay and Water
Creek) despite the presence of crustose coralline algae that produce high-Mg calcite (Tables 3 and 6). Percent total organic matter (TOM) was less than $12 \%$ throughout the bays, but higher at inner- and mid-bay sites than outer-bay sites (Table 3 ). Low $\mathrm{pH}_{\mathrm{T}}$ and high $p \mathrm{CO}_{2}$ conditions generated by respiration and oxidation of organic matter at MNC sites create a chemical environment that is conducive to dissolution of fine-grained sediments produced by calcareous green algae and coralline algae associated with these mangrove communities. Highest percentages of carbonate sediments (70 to $97 \%$ ) and high-Mg calcite was found at all MC and ROC sites. The only MNC site with high-Mg calcite was in Otter Creek. Our results suggest that dissolution of fine-grained carbonate sediments occurs in MNC areas with frequent exposure to $\mathrm{pH}_{\mathrm{T}}$ below 7.93 to 7.95 , and coral growth is limited to areas with minimum $\mathrm{pH}_{\mathrm{T}}$ above 7.93 (Fig. 3d).

\subsection{Process heterogeneity}

Process heterogeneity resulting from spatial variations in community structure and hydrographic conditions is a key factor in maintaining disequilibrium between coastal and open ocean water masses. Correlation of $\mathrm{nA}_{\mathrm{T}}$ and $\mathrm{nC}_{\mathrm{T}}$ can be used to indicate the potential influence of calcification, carbonate sediment dissolution, photosynthesis, and respiration on seawater carbonate chemistry (Suzuki and Kawahata, 2003). A linear regression slope approaching 2 indicates calcification and dissolution are dominant processes, and the slope can be used to calculate the ratio of net ecosystem calcification (NEC) to net community production (NCP). MNC sites generally showed a greater range of $\mathrm{nA}_{\mathrm{T}}$ and $\mathrm{nC}_{\mathrm{T}}$ and a greater influence from respiration and carbonate dissolution than MC and ROC sites (Fig. 5). This result is consistent with low $\mathrm{pH}_{\mathrm{T}}$, high $p \mathrm{CO}_{2}$, low mineral saturation state, and lower percentages of carbonate sediments characteristic of MNC sites. Eighteen of twenty-seven sites showed a correlation between $\mathrm{nA}_{\mathrm{T}}$ and $\mathrm{nC}_{\mathrm{T}}$ with $r^{2}$ greater than 0.5 (Table 7). NEC : NCP for these sites showed a wide range between 0.14 and 12.1 (Table 7) reflecting the strong effect of variation in community structure on these processes.

Lagrangian drifter studies conducted during August 2011 indicated that surface currents within the bays move primarily from the inner to outer bay due to prevailing easterly winds (McKenzie, 2012). Estimated water mass residence times are long (days) (McKenzie, 2012), which, combined with shallow water depths, increases the impact of NEC and NCP on seawater chemistry (Anthony et al., 2011). Carbonate sediment dissolution (a process that consumes $\mathrm{CO}_{2}$ and generates $\mathrm{HCO}_{3}^{-}$and $\mathrm{Ca}^{2+}$ ) at upstream, inner-bay $\mathrm{MNC}$ sites may provide a source of alkalinity to downstream coral sites that helps maintain mineral saturation states and supports coral calcification. This combined effect of heterogeneity in community structure, hydrography, and biologically driven changes in seawater chemistry has been demonstrated as an effective means to buffer decreases in mineral 

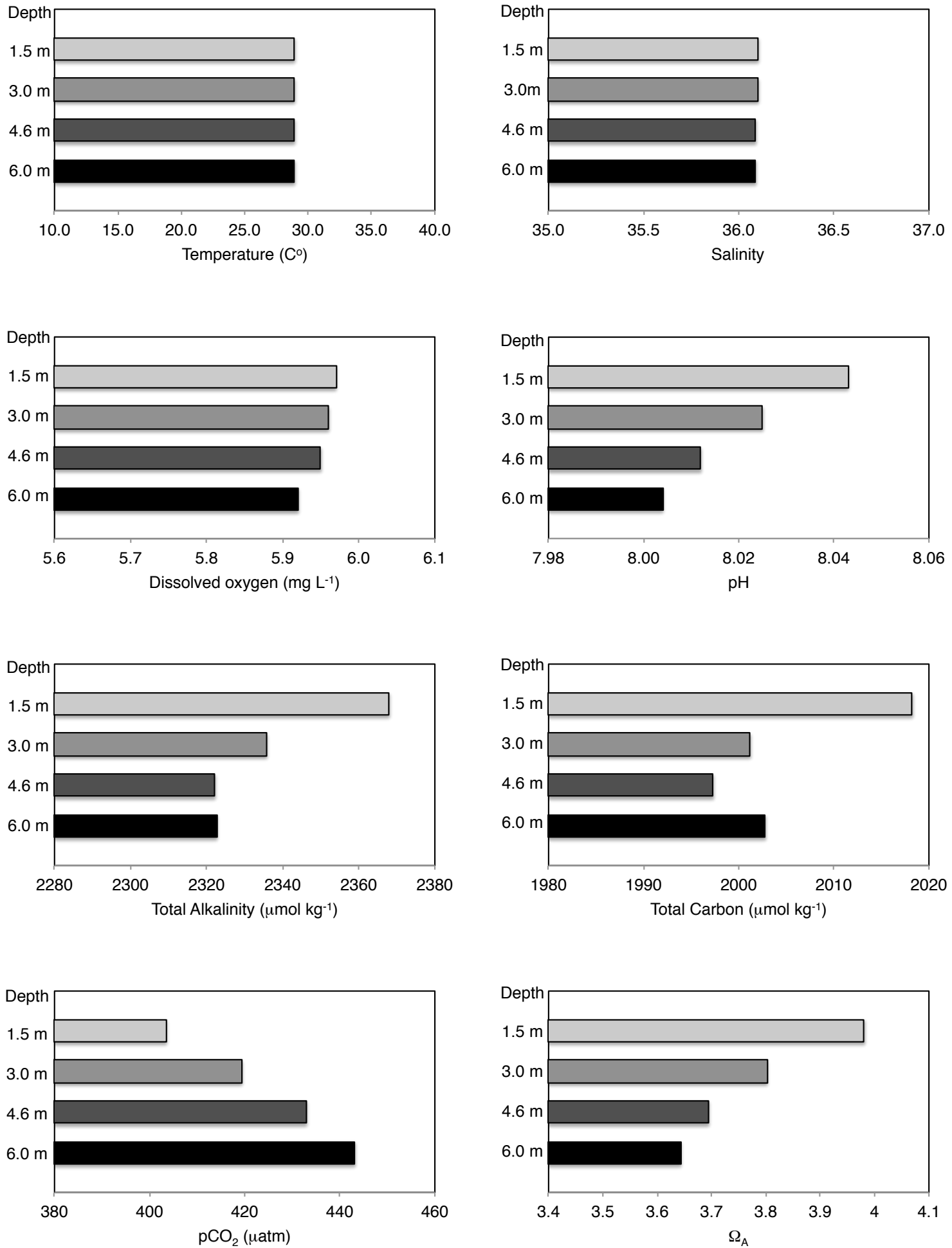

Figure 4. Vertical profile data of seawater chemical parameters collected at 07:00 on 19 July 2011 over coral habitat at $6.5 \mathrm{~m}$ water depth. Vertical axis is depth below sea surface. Also refer to Table 4. 
Table 4. Vertical profile data.

\begin{tabular}{ccccccccc}
\hline $\begin{array}{c}\text { Depth } \\
(\mathrm{m})\end{array}$ & $\begin{array}{c}\text { Temp. } \\
\left({ }^{\circ} \mathrm{C}\right)\end{array}$ & $\begin{array}{c}\text { Sal. } \\
(\mathrm{psu})\end{array}$ & $\begin{array}{c}\mathrm{DO} \\
\left(\mathrm{mg} \mathrm{L}^{-1}\right)\end{array}$ & $\mathrm{pH}_{\mathrm{T}}$ & $\begin{array}{c}T_{\mathrm{A}} \\
\left(\mu \mathrm{mol} \mathrm{kg}^{-1}\right)\end{array}$ & $\begin{array}{c}C_{\mathrm{T}} \\
\left(\mu \mathrm{mol} \mathrm{kg}^{-1}\right)\end{array}$ & $\begin{array}{c}p \mathrm{CO}_{2} \\
(\mu \mathrm{atm})\end{array}$ & $\Omega_{\mathrm{A}}$ \\
\hline 1.5 & 28.9 & 36.1 & 5.97 & 8.043 & 2368 & 2018 & 404 & 3.98 \\
3.0 & 28.9 & 36.1 & 5.96 & 8.025 & 2336 & 2001 & 419 & 3.80 \\
4.6 & 28.9 & 36.1 & 5.95 & 8.012 & 2322 & 1997 & 433 & 3.69 \\
6.0 & 28.9 & 36.1 & 5.92 & 8.004 & 2323 & 2003 & 443 & 3.64 \\
\hline
\end{tabular}

Vertical profile data were collected between 07:00 and 07:07 on 19 July 2011 near the mouth of Otter Creek at study site number STJ17 (Fig. 1). Also refer to Fig. 4.

Table 5. Long bay reef data.

\begin{tabular}{llccccccccc}
\hline Site & Date & $\begin{array}{c}\text { Time } \\
(\mathrm{AST})\end{array}$ & $\begin{array}{c}\text { Temp. } \\
\left({ }^{\circ} \mathrm{C}\right)\end{array}$ & $\begin{array}{c}\text { Sal. } \\
(\mathrm{psu})\end{array}$ & $\begin{array}{c}\mathrm{DO} \\
\left(\mathrm{mg} \mathrm{L}^{-1}\right)\end{array}$ & $\mathrm{pH}_{\mathrm{T}}$ & $\begin{array}{c}T_{\mathrm{A}} \\
\left(\mu \mathrm{mol} \mathrm{kg}^{-1}\right)\end{array}$ & $\begin{array}{c}C_{\mathrm{T}} \\
\left(\mu \mathrm{mol} \mathrm{kg}^{-1}\right)\end{array}$ & $\begin{array}{c}p \mathrm{CO}_{2} \\
(\mu \mathrm{atm})\end{array}$ & $\begin{array}{c}\Omega_{\mathrm{A}} \\
1\end{array}$ \\
\hline 16 Jul 2004 & $11: 00$ & 28.7 & 35.7 & 6.9 & 7.996 & 2267 & 1962 & 443 & 3.47 \\
1 & 18 Aug 2004 & $07: 00$ & 28.9 & 35.4 & 5.2 & 7.925 & 2283 & 2019 & 548 & 3.09 \\
1 & 19 Aug 2004 & $07: 00$ & 29.2 & 35.2 & 5.0 & 7.955 & 2309 & 2023 & 509 & 3.33 \\
2 & 16 Jul 2004 & $11: 00$ & 29.3 & 35.7 & ND & 8.031 & 2288 & 1954 & 404 & 3.80 \\
2 & 17 Jul 2004 & $07: 00$ & 28.3 & 35.7 & 4.6 & 7.943 & 2286 & 2014 & 520 & 3.14 \\
2 & 18 Aug 2004 & $07: 00$ & 28.6 & 35.4 & 5.3 & 7.937 & 2279 & 2010 & 528 & 3.12 \\
2 & 19 Aug 2004 & $07: 00$ & 29.1 & 35.2 & 4.5 & 7.894 & 2282 & 2033 & 595 & 2.93 \\
3 & 20 Jul 2004 & $11: 00$ & 28.8 & 35.7 & 7.2 & 8.006 & 2269 & 1956 & 431 & 3.55 \\
3 & 22 Aug 2004 & $07: 00$ & 29.0 & 34.9 & 4.7 & 7.950 & 2275 & 2000 & 510 & 3.22 \\
4 & 22 Aug 2004 & $07: 00$ & 29.0 & 34.9 & 4.9 & 7.936 & 2269 & 2002 & 529 & 3.13 \\
\hline
\end{tabular}

Long Bay reef data were collected from four locations at 07:00 or 11:00 AST. between 16 July and 22 August 2004. ND = no data. Latitude and longitude for reefs sites are as follows: site $1=18.337972,-64.675944 ; 2=18.337944,64.676028 ; 3=18.337833,-64.675861 ; 4=18.337806,64.675917$ (refer to Fig. 1 for reef location and to Fig. 3).

saturation state and increase calcification in downstream communities in experimental coral/macroalgal assemblages (Anthony et al., 2011) and in seagrass/coralline algae and coral/seagrass assemblages on coral reefs in Tanzania and Moorea (Kleypas et al., 2011; Semesi et al., 2009a, b). This same combination of spatial and temporal variations in community structure and processes in mangrove/coral habitats may help buffer against ocean acidification.

\subsection{Biological responses}

The presence of decades-old coral colonies in these mangrove-lined bays suggests adaptation to higher water temperatures and more resistance to and rapid recovery from bleaching events such as the one that was followed by severe mortality from disease in 2005 on the island's coral reefs. Coral surveys indicate at least 33 species of scleractinian corals are growing in Hurricane Hole Bays (Table 1). Many coral colonies are growing directly on or close to mangrove prop roots, and others grow on rocks or hard substrate close to shore to a depth of approximately $6 \mathrm{~m}$. Bleaching was observed on St. John's coral reefs (NPS, 2012) and in Hurricane Hole in 2010. Initial surveys of bleached and unbleached corals from November 2010 to January 2011 indicate that only 5 and $2 \%$ of $C$. natans colonies were bleached in Otter Creek and Water Creek, respectively, while 58.9 and $17.4 \%$ of D. labyrinthiformis colonies were bleached in Otter and Water creeks, respectively. We chose these two coral species as the focus of our observations because they were the most abundant major reef-building species in Hurricane Hole, they are thriving there despite a decline in relative and absolute abundance of both species on St. John reefs during the 2005/2006 bleaching and disease event (Whelan et al. 2007, Miller et al. 2009), and both species typically occur in exposed as opposed to shaded locations.

Re-examination of a subset of Otter Creek colonies in spring 2011 showed general recovery from bleaching but some mortality. Fisher's exact test results indicated that different proportions of $C$. natans $(72.5 \%$ shaded, $27.5 \%$ unshaded) and D. labyrinthiformis (18.2\% shaded, $81.8 \%$ unshaded) were found in shaded versus unshaded conditions $(p<0.0001)$ and had different levels of initial bleaching ( $p<0.0001, C$. natans: no shaded colonies bleached, $10.5 \%$ of unshaded colonies bleached; D. labyrinthiformis: $34.2 \%$ of shaded colonies bleached, $66.1 \%$ of unshaded colonies bleached). Different mortality outcomes were also observed combining partial and total mortality $(p=0.0327)$ (Fig. 6a and b, Table 8). There was no mortality of shaded $C$. natans colonies and $10.5 \%$ mortality in unshaded colonies. D. labyrinthiformis showed $10.5 \%$ mortality in shaded and 
Table 6. Carbonate mineralogical composition of surface sediments.

\begin{tabular}{lccc}
\hline \multirow{2}{*}{$\begin{array}{l}\text { Sample } \\
\text { location }\end{array}$} & \multicolumn{3}{c}{ Carbonate mineralogy } \\
& \% Aragonite & $\%$ Mg-calcite & \% Calcite \\
\hline STJ5 & 53.3 & 8.8 & 37.9 \\
STJ7 & 75.4 & 8.0 & 16.7 \\
STJ8 & 60.2 & 21.1 & 18.8 \\
STJ10 & 70.7 & 16.3 & 13.1 \\
STJ11 & 65.8 & 0.0 & 34.2 \\
STJ12 & 82.3 & 16.5 & 1.2 \\
STJ13 & 58.9 & 34.6 & 6.4 \\
STJ14 & 74.6 & 11.3 & 14.1 \\
STJ15 & 78.9 & 0.0 & 21.1 \\
\hline
\end{tabular}

$12.3 \%$ mortality in unshaded colonies, respectively. More $C$. natans colonies grew in the shade than $D$. labyrinthiformis colonies. The fact that $C$. natans occurred statistically more often in the shade and that few of these colonies bleached supports the role of shading in providing refuge conditions. Although more unshaded D. labyrinthiformis colonies bleached and bleaching of these was more severe, shaded colonies were not more likely to recover normal pigmentation. For this species, shading affected the proportion of colonies that initially bleached ( $p<0.0001)$, but not the outcome $(p=0.7582)$. Although more unshaded colonies of $D$. labyrinthiformis bleached, the mortality outcome for shaded and unshaded colonies was similar $(p=0.7508)$. Overall, recovery from bleaching was high, with little mortality. Only two $C$. natans colonies bleached. Both had partial mortality and none of the initially unbleached corals showed any mortality $(p<0.0001)$. Data in Table 8 were combined for both coral species into four categories and used to calculate log-odds ratios: (1) shaded, bleached; (2) shaded, unbleached; (3) unshaded, bleached; and (4) unshaded, unbleached (Table 8). Results indicate that the probability of unshaded corals bleaching relative to shaded corals is 8.84 at a $95 \%$ confidence interval.

All major Caribbean reef-building species, with the exception of the acroporids, were observed in Hurricane Hole. Over 40 species of scleractinian corals and 3 species of Millepora occur in the US Virgin Islands (Rogers et al., 2008), and 33 have been seen in the mangroves. A rigorous quantitative comparison of the relative and absolute abundance of all the species of corals in the mangroves versus on the reefs around St. John is not possible primarily because so many of the corals are inaccessible growing in shallow water in the prop roots, and standard monitoring methods cannot be used. However, one can estimate the relative abundance of some of the coral species in the mangroves and on the reefs qualitatively based on direct observations and photographs.

Data from the National Park Service (Atkinson and Miller, 2014) show species in the genus Orbicella consistently have had the highest cover on St. John's reefs. This Orbicella
Table 7. NEC : NEP ratios for study sites with $\mathrm{nA}_{\mathrm{T}}$ vs. $\mathrm{nC}_{\mathrm{T}} r^{2}>$ 0.5 .

\begin{tabular}{|c|c|c|c|c|c|}
\hline Date & Location & Site & NEC : NEP & LRE & $r^{2}$ \\
\hline \multirow[t]{9}{*}{ Nov 2010} & \multirow[t]{3}{*}{ Otter Creek } & $\mathrm{MC}$ & NA & $0.17570 x+2063$ & 0.12 \\
\hline & & $\mathrm{MNC}$ & 0.96 & $0.9795 x+376.87$ & 0.86 \\
\hline & & ROC & 12.11 & $2.1779 x-2098.5$ & 0.50 \\
\hline & \multirow[t]{3}{*}{ Water Creek } & $\mathrm{MC}$ & NA & $-0.2660 x+3000.5$ & 0.27 \\
\hline & & MNC & 0.33 & $0.5031 x+1354.2$ & 0.83 \\
\hline & & $\mathrm{ROC}$ & NA & $-0.1158 x+2684.9$ & 0.02 \\
\hline & \multirow[t]{3}{*}{ Princess Bay } & $\mathrm{MC}$ & 0.32 & $0.4936 x+1343.3$ & 0.57 \\
\hline & & $\mathrm{MNC}$ & 3.35 & $1.5414 x-823.71$ & 0.93 \\
\hline & & ROC & 0.75 & $0.8602 x+600.04$ & 0.91 \\
\hline \multirow[t]{9}{*}{ Jul 2011} & \multirow[t]{3}{*}{ Otter Creek } & $\mathrm{MC}$ & 1.63 & $1.2413 x-181.92$ & 0.87 \\
\hline & & $\mathrm{MNC}$ & NA & $0.3334 x+1616.5$ & 0.17 \\
\hline & & ROC & 1.27 & $1.1153 x+66.438$ & 0.70 \\
\hline & \multirow[t]{3}{*}{ Water Creek } & $\mathrm{MC}$ & 0.44 & $0.6069 x+1075.7$ & 0.68 \\
\hline & & MNC & 0.80 & $0.8863 x+516.13$ & 0.84 \\
\hline & & ROC & 1.22 & $1.0582 x+192.54$ & 0.58 \\
\hline & \multirow[t]{3}{*}{ Princess Bay } & $\mathrm{MC}$ & 0.18 & $0.3060 x+1661.5$ & 0.94 \\
\hline & & $\mathrm{MNC}$ & 0.44 & $0.6141 x+1069.5$ & 0.72 \\
\hline & & ROC & NA & $0.0369 x+2179.8$ & 0.01 \\
\hline \multirow[t]{9}{*}{ Jul 2012} & \multirow[t]{3}{*}{ Otter Creek } & $\mathrm{MC}$ & 0.28 & $0.4376 x+1435.1$ & 0.55 \\
\hline & & $\mathrm{MNC}$ & NA & $0.2189+1865.6$ & 0.32 \\
\hline & & ROC & NA & $0.2080 x+1889.5$ & 0.41 \\
\hline & \multirow[t]{3}{*}{ Water Creek } & $\mathrm{MC}$ & NA & $0.1773 x+1950.7$ & 0.45 \\
\hline & & $\mathrm{MNC}$ & 0.18 & $0.2965 x+1707.6$ & 0.84 \\
\hline & & $\mathrm{ROC}$ & NA & $0.2915 x+1723.4$ & 0.38 \\
\hline & \multirow[t]{3}{*}{ Princess Bay } & $\mathrm{MC}$ & 0.25 & $0.4042 x+1507.2$ & 0.89 \\
\hline & & $\mathrm{MNC}$ & 0.14 & $0.2513 x+1810.3$ & 0.95 \\
\hline & & ROC & 0.31 & $0.4740 x+1366.3$ & 0.85 \\
\hline
\end{tabular}

Ratios of net ecosystem calcification to net community production (NEC: NCP) were calculated from the slopes of best-fit linear regression lines for 18 of 27 site measurements showing a correlation between $\mathrm{nA}_{\mathrm{T}}$ and $\mathrm{nC}_{\mathrm{T}}$ with $r^{2}>0.5$. NEC: NCP was calculated using the expression $1 /[(2 / m)-1]$, where $m$ is the slope from the corresponding linear regression equation (LRE). MC is mangrove-coral site, MNC is mangrove no coral site, and ROC is rock outcrop coral site.

group is not as abundant in the mangroves as the two major reef-building species that we focused on in our research. The most common species in the mangroves are Colpophyllia natans, Diploria labyrinthiformis, Orbicella spp., Porites spp., and Agaricia spp. Colpophyllia natans and Diploria labyrinthiformis, the subject of the observations on bleaching and recovery reported here, have a higher relative and absolute abundance in some portions of Hurricane Hole than on the island's coral reefs based on data on coral cover. Furthermore, these two species declined in relative and absolute abundance on the reefs as a result of bleaching and disease in $2005 / 2006$. Many other species in the mangroves have an intermediate abundance. Two coral species (Mycetophyllia and Scolymia), represented by only a few individuals in the mangroves, are more often found in deeper water (greater than $10 \mathrm{~m}$ ) and are presumably able to survive because of shading by the mangroves.

PAR measurements made above the sea surface and at the seafloor at MC sites and ROC sites of similar depth during November 2010, July 2011, and July 2012 indicate that PAR was attenuated during peak daylight hours of 10:00 to 14:00 by $88.6 \pm 5.3 \%, 70.7 \pm 4.8 \%$, and $72.0 \pm 1.7 \%$ (Fig. 7), respectively, where corals grow shaded by the mangroves at MC sites. In addition to shading by mangrove trees, colored dissolved organic matter (CDOM) in the water near mangroves, especially where there is frequent freshwater input, could also attenuate harmful visible and ultraviolet radiation 

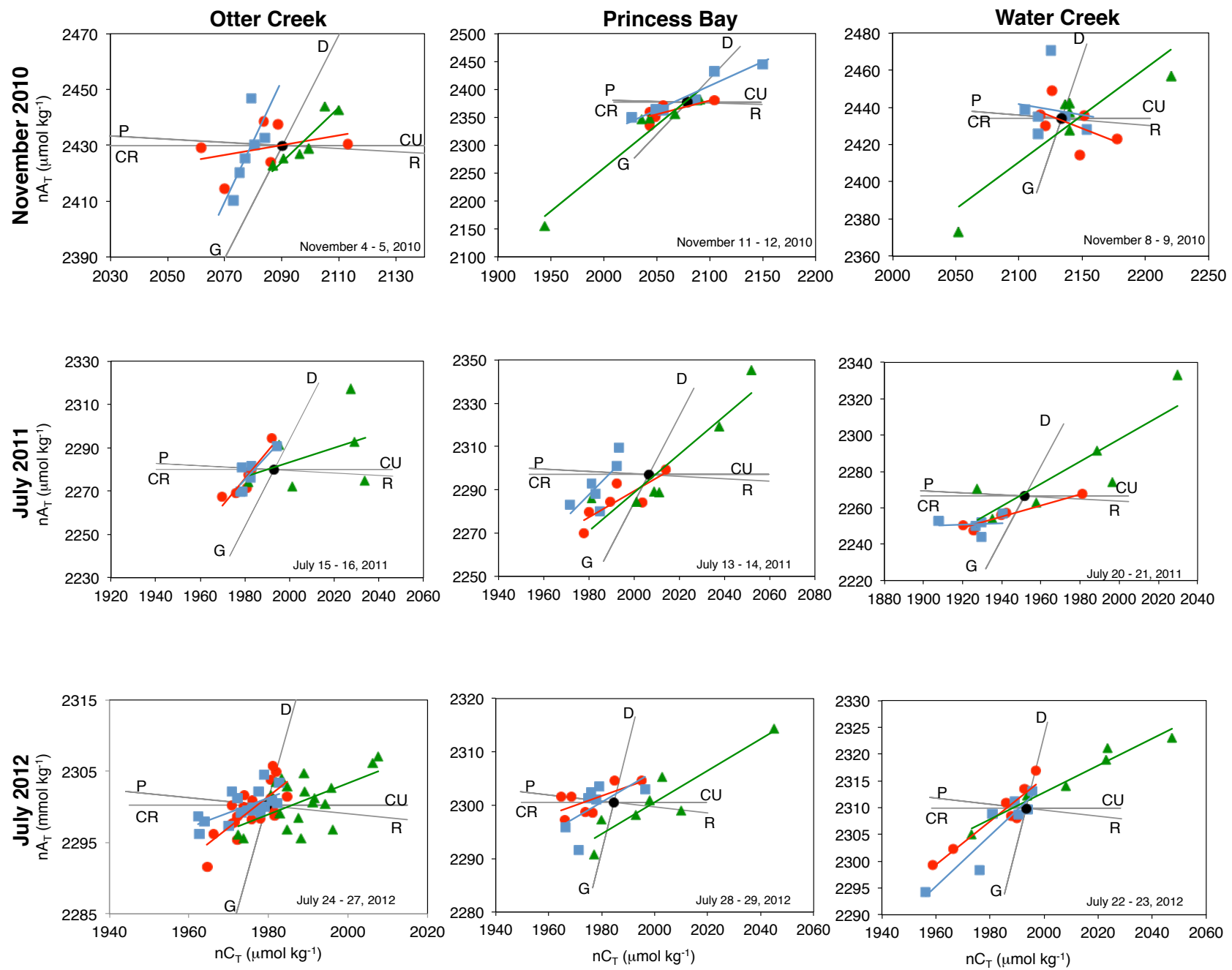

Rock Outcrop Coral

Mangrove Coral

Mangrove No Coral

Average $\mathrm{nA}_{\mathrm{T}}$ and $\mathrm{nC}_{\mathrm{T}}$

Figure 5. Salinity-normalized total alkalinity $\left(\mathrm{nA}_{\mathrm{T}}\right)$ and total carbon $\left(\mathrm{nC}_{\mathrm{T}}\right)$ plots with best-fit linear regressions (see Table 7 for equations and $r^{2}$ values) for November 2010, July 2011, and July 2012 in Otter Creek, Water Creek, and Princess Bay. Average $\mathrm{nA}_{\mathrm{T}}$ and $\mathrm{nC}_{\mathrm{T}}$ for each time period was calculated from all data collected from each site within each bay. Gray lines represent the theoretical impact of calcification $(\mathrm{G})$, carbonate sediment dissolution (D), photosynthesis (P), respiration (R), $\mathrm{CO}_{2}$ uptake $(\mathrm{CU})$, and $\mathrm{CO}_{2}$ release $(\mathrm{CR})$ on $A_{\mathrm{T}}$ and $C_{\mathrm{T}}$.

and reduce the photo-oxidative stress on corals (Fitt and Warner, 1995, Shick et al., 1996, Zepp et al., 2008, Ayoub et al., 2012). It is unlikely that CDOM is providing much additional shading in Hurricane Hole, but it could be a contributing factor. The water clarity is generally very high, particularly in shallow water near the mangrove prop roots at our study sites. PAR data in Fig. 7 shows that PAR at the rock outcrops which are very close to the mangroves is not considerably attenuated relative to PAR measured in-air indicating that CDOM is likely not contributing much to the attenuation of solar radiation.
Comparison of temperature records in the shallow waters of Hurricane Hole to coral reefs around St. John (Miller et al., 2009; National Park Service, 2012) indicate that corals growing in Hurricane Hole are exposed to higher $\left(0.5 \pm 0.5^{\circ} \mathrm{C}\right.$ on average) and more variable temperatures than coral reefs around the island (Fig. 8). Low bleaching and mortality have been observed for corals growing on nearshore reefs of Palau that have constant exposure to high temperatures, more variable temperatures, and high vertical attenuation of light caused by suspended particulate matter (van Woesik et al., 2012). Experiments with corals from a shallow lagoon in American Samoa suggested that thermal tolerance 
Table 8. Condition of colonies of Diploria labyrinthiformis and Colpophyllia natans during 2010-2011.

\begin{tabular}{lcccc}
\hline Colony condition & $\begin{array}{c}\text { D. labyrinthiformis } \\
\text { shaded }\end{array}$ & $\begin{array}{c}\text { D. labyrinthiformis } \\
\text { unshaded }\end{array}$ & $\begin{array}{c}\text { C. natans } \\
\text { shaded }\end{array}$ & $\begin{array}{c}\text { C. natans } \\
\text { unshaded }\end{array}$ \\
\hline Total number of colonies & 38 & 171 & 50 & 19 \\
\hline Bleached to dead & 1 & 5 & 0 & 0 \\
Bleached to partial mortality & 1 & 10 & 0 & 2 \\
Bleached to unbleached & 11 & 98 & 0 & 0 \\
Unbleached to dead & 1 & 2 & 0 & 0 \\
Unbleached to partial mortality & 1 & 4 & 0 & 0 \\
Unbleached to unbleached & 23 & 52 & 50 & 17 \\
\hline Summary & \multicolumn{2}{c}{ Unshaded } \\
\hline Bleached & Shaded & 13 & \multicolumn{2}{c}{115} \\
Unbleached & 75 & \multicolumn{3}{c}{75} \\
\hline
\end{tabular}

Bleached-shaded and -unshaded, and unbleached-shaded and -unshaded data were combined for both species and used for log-odds ratio statistics.

a.

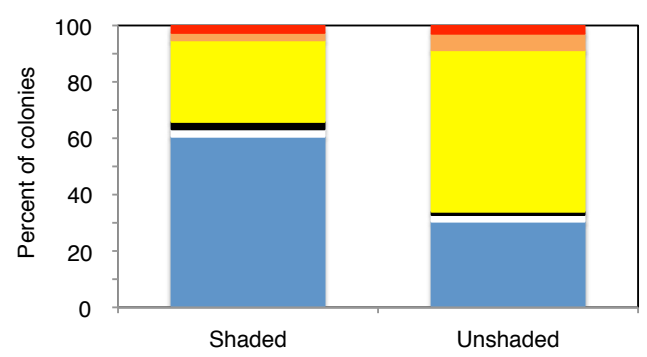

b.

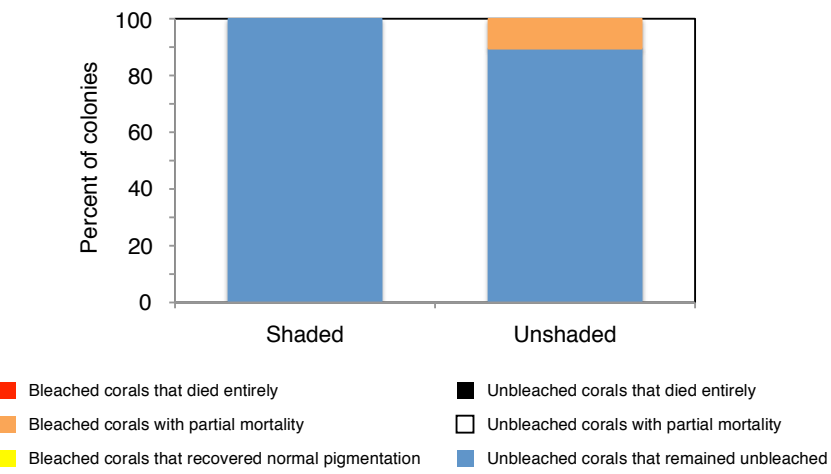

Figure 6. Recovery results for shaded vs. unshaded (a) Diploria labyrinthiformis ( $n=38$ and $n=171$ for shaded and unshaded colonies, respectively) and (b) Colpophyllia natans ( $n=50$ and $n=19$ for shaded and unshaded colonies, respectively) from 2010 to 2011. Also refer to Table 8 .

increased with previous exposure to highly variable temperatures (Oliver and Palumbi, 2011). Similarly, the resilience of mangrove corals following elevated temperatures likely results from relief from solar radiation stress provided by shading of corals by mangroves.

\section{Alternative refuges and resiliency factors}

As reefs decline worldwide and sea level continues to rise, alternative shallow-water refuges like mangrove-coral habitats may be critical for insuring the survival of coral species. Few refuges have been identified to date. Potential refuges from thermal and irradiance stress have been suggested based on modeling (e.g., Karnauskas and Cohen, 2012; Fine et al., 2013) and field research (van Woesik et al., 2012). In Palau, corals exhibited less bleaching and mortality in bays where the highest temperatures were recorded, because of attenuation of light (shading) by suspended particulate matter (van Woesik et al., 2012). Cloud cover substantially reduced bleaching in the Society Islands in 1998, showing the role of increased solar irradiance in producing thermal stress in corals (Mumby et al., 2001). Based on modeling, Fine et al. (2013) suggest that the Gulf of Aqaba (Red Sea), where corals have very high bleaching thresholds, functions as a refuge because of its particular geographic configuration, with a thermal barrier at its southernmost end selecting more resistant coral genotypes. Glynn (1996) proposed that reefs near cool, upwelled waters might serve as refuges. Karnauskas and Cohen (2012) used models to show that warming around a limited number of Pacific island reefs might be ameliorated by enhanced topographic upwelling accompanying a strengthening of the equatorial undercurrent. Riegl and Piller (2003) found some evidence of the role of upwelling in mitigating thermal stress in the Bahamas and South Africa. However, Chollett et al. (2010) showed that upwelling does not ensure that nearby reefs will act as refuges.

Glynn (1996) also suggested that reefs far from detrimental human activities might serve as refuges. However, several remote reefs that Riegl and Piller (2003) examined in the Caribbean had sustained significant loss of coral from bleaching and disease. The potential for deep reefs (often defined as $30 \mathrm{~m}$ and deeper) to serve as refuges for corals 


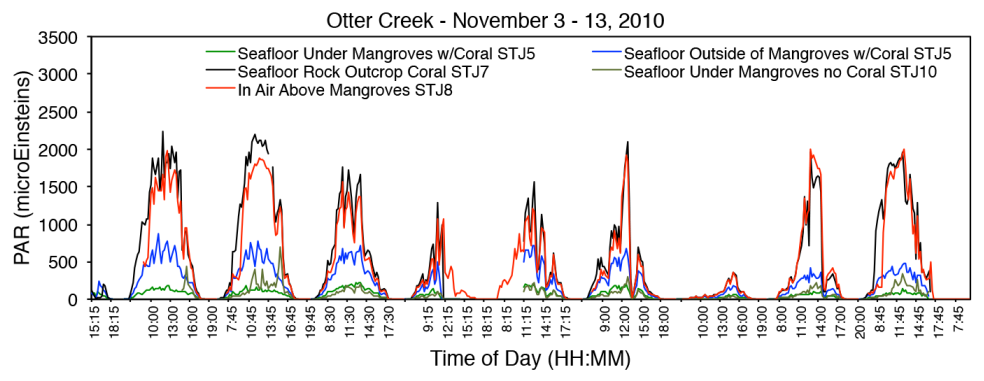

b.

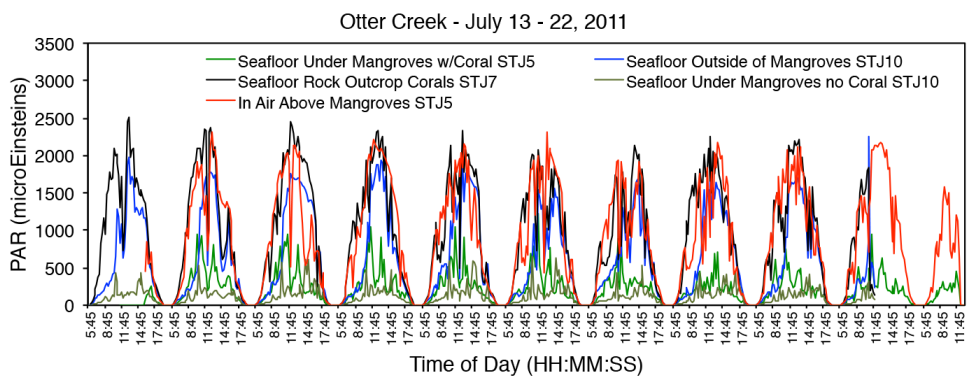

c.

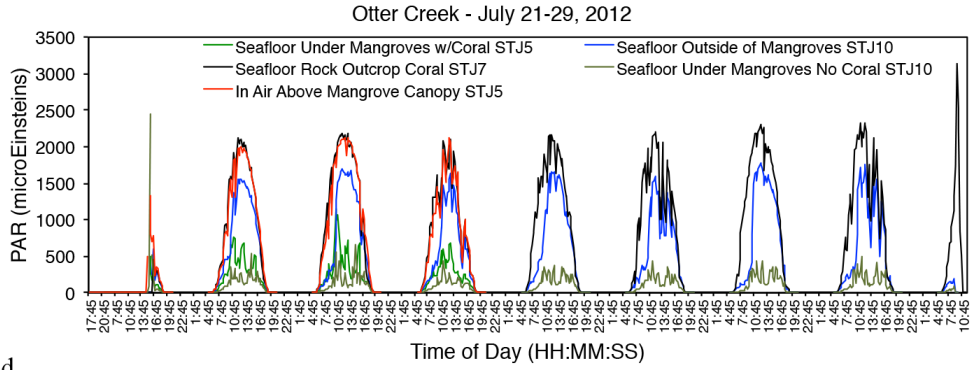

d.
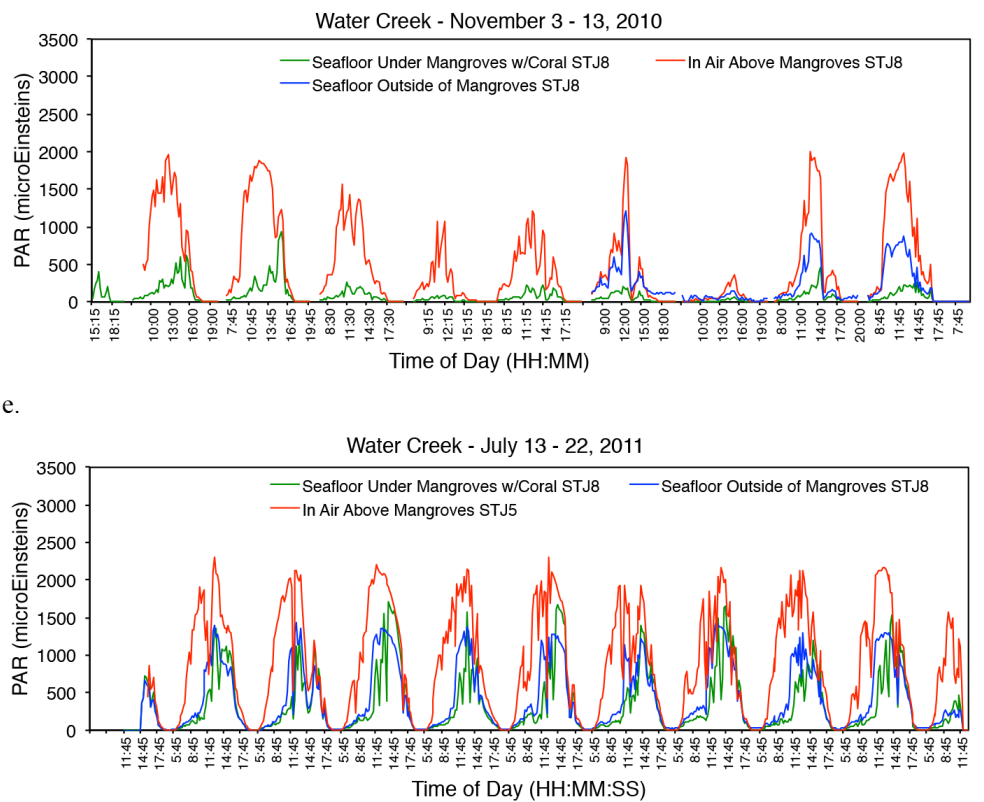

Figure 7. Photosynthetically active radiation (PAR) measurements at study sites in Otter Creek $(\mathbf{a}, \mathbf{b}$, and $\mathbf{c})$ and Water Creek (d and e). Measurements represent 15 min averages. STJ numerals indicate PAR sensor locations as referenced in Fig. 1. Data available at http: //doi.pangaea.de/10.1594/PANGAEA.825752. 


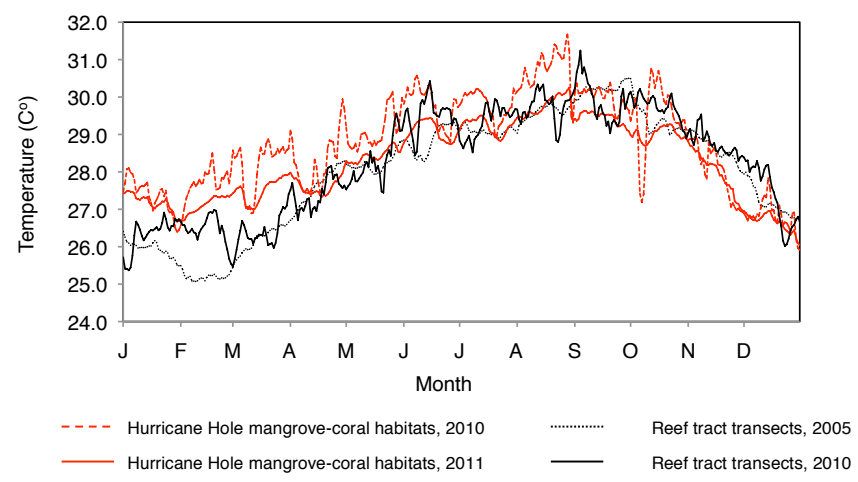

Figure 8. Temperature trends from mangrove-coral and reef tract habitats. Hurricane Hole temperature data were averaged from 18 data loggers distributed throughout Hurricane Hole bays (Table 2). Temperature measurements were recorded every $2 \mathrm{~h}$ and daily averages were generated from all sites in Hurricane Hole and from 6 reef sites around St. John. Data are available at http://doi.pangaea. de/10.1594/PANGAEA.825752.

and sources of replenishing larvae for shallower reef zones may be limited (Bongaerts et al., 2010). Deep (and moderately deep) reefs are not immune to major stressors including bleaching, disease (e.g. Riegl and Piller, 2003; Menza et al., 2007; Smith et al., 2010), and ocean acidification. Many coral species do not grow over an entire depth gradient, many do not broadcast (spawn) larvae, and deep corals may not, therefore, provide larvae that can settle and survive in shallow waters. Recent studies indicate that some corals living on reefs downstream from seagrass beds and macroalgal communities where photosynthesis elevates $\Omega_{\mathrm{A}}$ may be protected from ocean acidification (Manzello et al., 2012; Kleypas et al., 2011; Semesi et al., 2009a and b). However, many of those reefs may not be protected from thermal stress. Identification and protection of natural, alternative, shallow-water refuges is essential as one of the few viable management strategies for sustaining coral and other reef species, and it provides one of the only direct actions that can be taken locally to manage climate change impacts (Salm et al., 2006).

The unlikely association of corals with mangroves in many coastal ecosystems due to unsuitable growth conditions has dissuaded previous consideration of these habitats as potential coral refuges. Many mainland mangrove habitats especially those with large watersheds and high rates of freshwater runoff are not likely candidates for coral refuges. Despite the fact that St. John is exposed to episodic storm events with high rainfall that can briefly lower salinity (for example as shown in our November 2010 data), corals are thriving in the bays of Hurricane Hole and have been for decades, partially because the island has no perennial streams. Study sites in Princess Bay showed lower coral diversity and abundance than in Otter and Water creeks perhaps because it receives more freshwater runoff due to a larger watershed size. However, data are too few to quantify physical constraints on topographic boundaries that limit refuge potential for these coastal habitats. Numerous small tropical islands worldwide have physical characteristics similar to the US Virgin Islands (for example where freshwater input is limited due to small watersheds and no permanent sources of freshwater inflow) and the potential for suitable mangrove-coral refuge conditions. Our findings identify the first naturally existing, alternative refuge from climate change for reef-building corals and provide baseline resiliency factors to assist in identifying and characterizing mangrove-coral habitats and other alternative refuges around the world. Mangrove-coral habitats provide evidence of ecosystem transition that may be a response to pressures from unprecedented rates of recent climate change. Evidence of onshore migrations of coral in response to past changes in sea level rise is well documented in the geologic record (e.g. Hopley et al., 1983; Neumann and Macintyre, 1985). However, evidence for co-location of live corals and mangroves is not. These habitats may serve as an example of a novel coastal ecosystem (Graham et al., 2014) resulting from differential species responses, and provide insights into future evolution of tropical coastal ecosystems with increasing sea level rise, thermal stress, and ocean acidification.

We consider the St. John mangrove habitat as a refuge for corals because it provides relief from thermal and photooxidative stress through shading by mangroves and variability of seawater temperatures, and because biological and sedimentological processes buffer declines of $\mathrm{pH}$ and carbonate mineral saturation states that can impede growth of calcifying organisms. Our study showed that two major reef builders exhibited different responses to elevated temperatures. High diversity and variable response of reef organisms to climate change increases the likelihood that at least some species will be able to persist in locations with particular environmental conditions in the face of changing climate (Rogers, 2013). Coral diversity within the mangroves could help make these systems more resilient to future stresses. Exposure to warmer and more variable conditions in the mangroves may also facilitate adaptation of these corals to higher temperatures and may enhance resiliency for future expansion under changing environmental conditions (van Woesik et al., 2012; Palumbi et al., 2014; Oliver and Palumbi, 2011). Carbonate mineral saturation states and $\mathrm{pH}$ on a nearby reef were lower than in the mangrove coral habitats. Furthermore, $\Omega_{\mathrm{A}}$ and $p \mathrm{CO}_{2}$ on the reef surpassed critical carbonate dissolution threshold ranges while those in mangrove coral habitats generally did not. We suggest that the ability of a refuge environment to consistently buffer declines in $\mathrm{pH}$ and carbonate saturation state (as opposed to periodically elevating them) to keep them from surpassing critical thresholds relative to reef environments is the most important factor for providing relief from ocean acidification. The physicochemical conditions and benthic heterogeneity in these mangrove-coral habitats showed the potential to buffer against ocean acidification like the seagrass/coralline algae/coral assemblages 
Table 9. Resiliency factors for mangrove-coral refuges.

\begin{tabular}{|c|c|}
\hline Resiliency factor & Local condition at mangrove-coral sites in St. John, US Virgin Islands \\
\hline \multicolumn{2}{|l|}{ Diversity and response of organisms } \\
\hline High diversity of coral species & More than 30 coral species identified \\
\hline Variable response of organisms & $\begin{array}{l}\text { Preferential growth of } C \text {. natans in shaded areas, more bleaching } \\
\text { of exposed than shaded } D \text {. labyrinthiformis colonies }\end{array}$ \\
\hline \multicolumn{2}{|l|}{ Heterogeneity and habitat proximity } \\
\hline . Community heterogeneity & $\begin{array}{l}\text { Collocation of corals and mangroves, upstream to downstream tran- } \\
\text { sition from mangrove/seagrass/algae to mangrove/coral habitat }\end{array}$ \\
\hline Available substrate for coral settlement & Prop roots, hard bottom \\
\hline $\begin{array}{l}\text { Low NEC : NCP ratios at upstream or coral locations and } \\
\text { proximity to coral growth sites }\end{array}$ & $\begin{array}{l}\text { Average NEC: NEP of } 0.5 \text { to } 0.9 \text { at mangrove-coral (MC) sites } \\
\text { and upstream mangrove, calcareous algae, seagrass communities } \\
\text { (MNC), respectively }\end{array}$ \\
\hline \multicolumn{2}{|l|}{ Hydrographic and chemical conditions } \\
\hline - Limited or no influence from permanent freshwater inflow & No permanent or frequent freshwater inflow \\
\hline Long water mass residence times & Days (McKenzie, 2012) \\
\hline $\begin{array}{l}\text { Hydrographic conditions that maintain substrate appropriate } \\
\text { for coral settlement and growth }\end{array}$ & $\begin{array}{l}\text { Periodic influence from storm waves that prevents settlement of } \\
\text { fine-grained sediments, low TOM }(<12 \%),>69 \% \text { sand and } \\
\text { gravel }\end{array}$ \\
\hline . Seawater chemistry conducive to coral growth & Minimum pH 7.93, maximum $p \mathrm{CO}_{2} 550 \mu$ atm, minimum $\Omega_{\mathrm{A}} 2.82$ \\
\hline \multicolumn{2}{|l|}{ Exposure } \\
\hline $\begin{array}{l}\text { Consistent exposure of corals to higher, more variable tem- } \\
\text { peratures }\end{array}$ & $\begin{array}{l}\text { Average temperature } 0.5 \pm 0.5^{\circ} \mathrm{C} \text { higher than reef tract tempera- } \\
\text { tures }(2010)\end{array}$ \\
\hline Physical shading from solar radiation & $\begin{array}{l}\text { Mangrove canopy attenuates }>70 \% \text { of incident photosynthetically } \\
\text { active radiation (PAR) }\end{array}$ \\
\hline
\end{tabular}

of Tanzania and Malaysia (Kleypas et al., 2011; Semesi et al., 2009a, b). Key resiliency factors for mangrove-coral habitats include (1) high diversity and variable response of coral species to climate change stressors, (2) heterogeneity of benthic community composition, processes, and proximity of different habitat types, (3) hydrographic conditions that amplify biogeochemical effects on seawater chemistry and promote chemical characteristics that support coral growth, and (4) exposure to variable water temperatures and physical shading of corals from solar radiation (Table 9). The appropriate combination of all of these factors for creating refuge conditions is not generally characteristic of most coral reef environments. Thus, only a few reef systems that protect against increased temperatures, solar radiation, or ocean acidification have been identified, and none have been identified that protect from all three stressors like the mangrovecoral habitats of St. John.

Acknowledgements. We would like to thank Nasseer Idrisi and Sophia McKenzie for collection and analysis of hydrographic data. Our gratitude goes to Chelsea Bliss and Rich Young for total alkalinity and total carbon measurements. We would like to thank Hannah Yates for assisting with collection of seawater samples and chemical parameter measurements, and Casey Evans and Miranda Bona for assisting with coral surveys. Thanks to Andrea Atkinson with the National Park Service and John Lisle with the US Geological Survey for statistical analysis of the coral data. We would like to thank Robin Clair of Estate Zootenvaal for logistical support and Candace Oviatt for early comments on the manuscript. We appreciate insightful comments from two anonymous reviewers that greatly improved our manuscript. The research was funded by the Park-Oriented Biological Support Program of the US Geological Survey and National Park Service, and by the Southeast Ecological Science Center and the Coastal and Marine Geology Program of the US Geological Survey.

Edited by: W. Kiessling

\section{References}

Anthony, K. R. N., Kleypas, J. A., and Gattuso, J.-P.: Coral reefs modify their seawater carbon chemistry - implications for impacts of ocean acidification, Glob. Change Biol., 17, 3655-3666, 2011.

Atkinson, A. and Miller, W. J.: Coral relative abundance at index sites in Virgin Islands National Park, Generic Multimedia2211046, https://irma.nps.gov/App/Reference/Profile/2211046, 2014.

Ayoub, L. M., Hallock, P., Coble, P. G., and Bell, S. S.: MAA-like absorbing substances in Florida Keys phytoplankton vary with distance from shore and CDOM: Implications for coral reefs, JEMBE, 420, 91-98, 2012.

Baker, A. C., Glynn, P. W., and Riegl, B.: Climate change and coral reef bleaching: an ecological assessment of long-term impacts, recovery trends and future outlooks, Estuar. Coast. Shelf S., 40, 435-471, 2008.

Beets, J., Lewand, L., and Zullo, E.: Marine community descriptions and maps of bays within the Virgin Islands National Park/Biosphere Reserve, Virgin Islands Resource Management 
Cooperative: Biosphere Research Report 2. US Department of the Interior, National Park Service, 117 pp., 1986.

Berkelmans, R.: Time-integrated thermal bleaching thresholds of reefs and their variation on the Great Barrier Reef, Mar. Ecol. Prog. Ser., 229, 73-82, 2002.

Bongaerts, P., Ridgway, T., Sampayo, E. M., and Hoegh-Guldberg, O.: Assessing the "deep reef refugia" hypothesis: focus on Caribbean reefs, Coral Reefs, 29, 309-327, 2010.

Burke, L. M., Reytar, K., Spalding, M., and Perry, A.: Reefs at risk revisited, World Resources Institute, Washington, DC, 114 pp., 2011.

Chollett, I., Mumby, P. J., and Cortes, J.: Upwelling areas do not guarantee refuge for coral reefs in a warming ocean, Mar. Ecol. Prog. Ser., 416, 47-56, 2010.

Dean, W. E.: Determination of carbonate and organic matter in calcareous sediments and sedimentary rocks by loss on ignition: comparison with other methods, J. Sed. Pet., 44, 242-248, 1974. Dickson, A. G.: Standard potential for the reaction: $\operatorname{AgCl}(\mathrm{s})+1 / 2$ $\mathrm{H}_{2}(\mathrm{~g})=\mathrm{Ag}(\mathrm{s})+\mathrm{HCl}(\mathrm{aq})$, and the standard acidity constant of the ion $\mathrm{HSO}_{4}^{-}$in synthetic seawater from 273.15 to $318.15 \mathrm{~K}$, J. Chem. Therm., 22, 113-127, 1990.

Dickson, A. G. and Millero, J. J.: A comparison of the equilibrium constants for the dissociation of carbonic acid in seawater media, Deep-Sea Res., 34, 1733-1743, 1987.

Dickson, A. G., Sabine, C. L., and Christian, J. R.: Guide to best practices for ocean $\mathrm{CO}_{2}$ measurements, in: PICES Special Publication, 3, 191 pp., 2007.

Eakin, C. M., Lough, J. M., and Heron, S. F.: Climate variability and change: monitoring data and evidence for increased coral bleaching stress, in: Coral Bleaching, Springer, Heidelberg, Germany, 41-67, 2009.

Fabricius, K. E., Langdon, C., Uthicke, S., Humphrey, C., Noonan, S., De'ath, G., Okazaki R., Muehllehner, N., Glas, M. S., and Lough, J. M.: Losers and winners in coral reefs acclimatized to elevated carbon dioxide concentrations, Nat. Clim. Change, 1, 165-169, 2011.

Fine, M., Gildor, H., and Genin, A.: A coral reef refuge in the Red Sea, Glob. Change Biol., 19, 3640-3647, 2013.

Fitt, W. K. and Warner, M. E.: Bleaching patterns of four species of Caribbean reef corals, Biol. Bull., 189, 298-307, 1995.

Fitt, W. K., Brown, B. E., Warner, M. E., and Dunne, P.: Coral bleaching: interpretation of thermal tolerance limits and thermal thresholds in tropical corals, Coral Reefs, 20, 51-65, 2001.

Folk, R. L.: Petrology of Sedimentary Rocks, Hemphill Publishing Company, Austin, 37-38, 1965.

Gibbs, R. J.: A settling tube for sand-sized analysis, J. Sed. Pet., 44, 583-588, 1974.

Glynn, P. W.: Coral reef bleaching: facts, hypotheses and implications, Global Change Biol., 2, 495-509, 1996.

Graham, N. A. J., Cinner, J. E., Norstrom, A. V., and Nystrom, M.: Coral reefs as novel ecosystems: embracing new futures, Curr. Opin. Environ. Sustain., 7, 9-14, 2014.

Hoegh-Guldberg, O.: Coral reef ecosystems and anthropogenic climate change, Reg. Env. Change, 11, S215-227, 2011.

Hoegh-Guldberg, O., Mumby, P. J., Hooten, A. J., Steneck, R. S., Greenfield, P., Gomez, E., Harvell, C. D., Sale, P. F., Edwards, A. J., Caldeira, K., Knowlton, N., Eakin, C. M., Iglesias-Prieto, R., Muthiga, N., Bradbury, R. H., Dubi, A., and Hatziolos, M. E.:
Coral reefs under rapid climate change and ocean acidification, Science, 318, 1737-1742, 2007.

van Hooidonk, R., Manyard, J. A., Manzello, D., and Planes, S.: Opposite latitudinal gradients in projected ocean acidification and bleaching impacts on coral reefs, Glob. Change Biol., 20, 103 112, 2014.

Hopley, D., Slocombe, A. M., Muir, F., and Grant, C.: Nearshore fringing reefs in North Queensland, Coral Reefs, 1, 151-160, 1983.

Karnauskas, K. and Cohen, A.: Equatorial refuge amid tropical warming, Nat. Clim. Change, 2, 530-534, 2012.

Keller, B. D., Gleason, D. F., McLeod, E., Woodley, C. M., Airame, S., Causey, B. D., Friedlander, A. M., Grober-Dunsmore, R., Johnson, J. E., Miller, S. L., and Steneck, R. S.: Climate change, coral reef ecosystems, and management options for marine protected areas, Environ. Manage., 44, 1069-1088, 2009.

Keppel, G., Van Niel, K. P., Wardell-Johnson, G. W., Yates, C. J., Byrne, M., Mucina, L., Schut, A. G. T., Hopper, S. D., and Franklin, S. E.: Refugia: identifying and understanding safe havens for biodiversity under climate change, Global Ecol. Biogeogr., 21, 393-404, 2012.

Kleypas, J. A. and Yates, K. K.: Coral reefs and ocean acidification, Oceanography, 22, 108-117, 2009.

Kleypas, J. A., Anthony, K. R. N., and Gattuso, J-P.: Coral reefs modify their seawater carbon chemistry - study from a barrier reef (Moorea, French Polynesia), Glob. Change Biol., 17, 36673678, 2011.

Langdon, C., Broecker, W. S., Hammond, D. E., Glenn, E., Fitzsimmons, K., Nelson, S. G., Peng, T.-H., Hajdas, I., and Bonani, G.: Effect of elevated $\mathrm{CO}_{2}$ on the community metabolism of an experimental coral reef, Global Biogeochem. Cy., 17, 11-1-11-14, 2003.

Lesser, M. P.: Coral bleaching: causes and mechanisms, in: Coral Reefs: An Ecosystem in Transition, Springer, Dordrecht, 405419, 2011.

Macintyre, I. G., Goodbody, I., Rutzler, K., Littler, D. S., and Littler, M. M.: A general biological and geological survey of the rims of ponds in the major mangrove islands of the Pelican Cays, Belize, Atoll Res. Bull., 467, 13-44, 2000.

Manzello, D. P., Enochs, I. C., Melo, N., Gledhill, D. K., and Johns, E. M.: Ocean acidification refugia of the Florida Reef Tract, PLoS ONE, 7, e41715, doi:10.1371/journal.pone.0041715, 2012.

McClanahan, T. R., Maina, J. M., and Muthiga, N. A: Associations between climate stress and coral reef diversity in the western Indian Ocean, Glob. Change Biol., 17, 2023-2032, 2011.

McKenzie, S.: Influence of oceanographic processes on the distribution of coral communities in Hurricane Hole, St. John, United States Virgin Islands, MS thesis, University of the Virgin Islands, US Virgin Islands, 51 pp., 2012.

Menza, C., Kendall, M., Rogers, C., and Miller, J.: A deep reef in deep trouble, Continent. Shelf Res., 27, 2224-2230, 2007.

Merbach, C., Culberson, C. H., Hawley, J. E., and Pytdowicz, R. M.: Measurement of the apparent dissociation constants of carbonic acid in seawater at atmospheric pressure, Limnol. Oceanogr., 18, 897-907, 1973.

Miller, J., Muller, E., Rogers, C., Waara, R., Atkinson, A., Whelan, K. R. T., Patterson, M., and Witcher, B.: Coral disease following 
massive bleaching in 2005 causes $60 \%$ decline in coral cover on reefs in the US Virgin Islands, Coral Reefs, 28, 925-937, 2009.

Milliman, J. D.: Marine Carbonates, Springer-Verlag, New York, 1974.

Mumby, P. J. and Steneck, R. S.: Coral reef management and conservation in light of rapidly evolving ecological paradigms, Trends Ecol. Evol., 23, 555-563, 2008.

Mumby, P. J., Chisholm, J. R. M., Edwards, A. J., Andrefouet, S., and Jaubert, J.: Cloudy weather may have saved Society Island reef corals during the 1998 ENSO event, Mar. Ecol. Prog. Ser., 222, 209-216, 2001.

National Park Service South Florida/Caribbean Network: Annual administrative report (FY 2011) and work plan (FY 2012) for inventories and vital signs monitoring: South Florida/Caribbean Network, Natural Resource Report NPS/SFCN/NRR, National Park Service, Fort Collins, Colorado, 2012/488, 2012.

Neumann, A. C. and Macintyre, I.: Reef response to sea level rise: keep-up, catch-up or give up, in: Proceedings of the Fifth International Coral Reef Congress, 3, Tahiti, 27 May - 1 June 1985, 105-110, 1985.

Oliver, T. A. and Palumbi, S. R.: Do fluctuating temperature environments elevate coral thermal tolerance?, Coral Reefs, 30, 429440, 2011.

Palumbi, S. R., Barshis, D. J., Traylor-Knowles, N, and Bay, R. A.: Mechanisms of reef coral resistance to future climate change, Science, 344, 895-898, 2014.

Pierrot, D. E., Lewis, E., and Wallace, D. W. R.: Ms Excel program developed for $\mathrm{CO}_{2}$ system calculations, ORNL/CDIAC105a, Carbon Dioxide Information Analysis Center, Oak Ridge National Laboratory, US Department of Energy, Oak Ridge, Tennessee, 2006.

Rankin, D. W.: Geology of St. John, US Virgin Islands, US Dept. of Interior, 1631 pp., 2002.

Riegl, B. and Piller, W. E.: Possible refugia for reefs in times of environmental stress, Int. J. Earth Sci., 92, 520-531, 2003.

Rogers, C. S.: Coral reef resilience through biodiversity, ISRN Oceanography: Article ID 739034, 18 pp., 2013.

Rogers, C. S. and Herlan, J. J.: Life on the edge: corals in mangroves and climate change, in: Proceedings of the 12th International Coral Reef Symposium, Cairns, Australia, 5 pp., 2012.

Rogers, C. S., Miller, J., Muller, E. M., Edmunds, P., Nemeth, R. S., Beets, J. P., Friedlander, A. M., Smith, T. B., Boulon, R., Jeffrey, C. F. G., Menza, C., Caldow, C., Idrisi, N., Kojis, B., Monaco, M. E., Spitzack, A., Gladfelter, E. H., Ogden, J. C., Hillis-Starr, Z., Lundgren, I., Schill, W. B., Kuffner, I. B., Richardson, L. L., Devine, B., Voss, J.: Ecology of Coral Reefs in the US Virgin Islands, Chapter 8, in: Riegl, B. and Dodge, R. E., Coral Reefs of the USA, Springer, 303-374, 2008.

Rutzler, K., Diaz, M. C., Van Soest, R. W. M., Zea, S., Smith, K. P., Alvarez, B., and Wulff, J.: Diversity of sponge fauna in mangrove ponds, Pelican Cays, Belize, Atoll Res. Bull., 229, 466495, 2000
Salm, R. V., Done, T., and Mcleod, E.: Marine protected area planning in a changing climate, in: Coral Reefs and Climate Change: Science and Management, American Geophysical Union, Washington, DC, 207-221, 2006.

Semesi, S., Beer, S., and Bjork, M.: Seagrass photosynthesis controls rates of calcification and photosynthesis of calcareous macroalgae in a tropical seagrass meadow, Mar. Ecol. Prog. Ser., 382, 41-47, 2009a.

Semesi, S., Kangwe, J., and Bjork, M.: Alterations in $\mathrm{pH}$ and $\mathrm{CO}_{2}$ affect calcification and photosynthesis in the tropical coralline alga, Hydrolithon sp. (Rhodophyta), Estuar. Coastal Shelf S., 84, 337-341, 2009b.

Silverman, J., Lazar, B., Cao, L., Caldeira, K., and Erez, J.: Coral reefs may start dissolving when atmospheric $\mathrm{CO}_{2}$ doubles, Geophys. Res. Lett., 36, L05606, doi:10.1029/2008GL036282, 2009.

Smith, T. B., Blondeau, J., Nemeth, R. S., Pittman, S. J., Calnan, J. M., Kadison, E., and Gass, J.: Benthic structure and cryptic mortality in a Caribbean mesophotic coral reef bank system, the Hind Bank Marine Conservation District, US Virgin Islands, Coral Reefs, 29, 289-308, 2010.

Suzuki, S. and Kawahata, H.: Carbon budget of coral reef systems: an overview of observations in fringing reefs, barrier reefs and atolls in the Indo-Pacific regions, Tellus 55B, 428-444, 2003.

West, J. M. and Salm, R. V.: Resistance and resilience to coral bleaching: implications for coral reef conservation and management, Cons. Biol., 17, 956-967, 2003.

Whelan, K. R. T., Miller, J., Sanchez, O., and Patterson, M.: Impact of the 2005 coral bleaching event on Porites porites and Colpophyllia natans at Tektite Reef, US Virgin Islands, Coral Reefs, 26, 689-693, 2007.

van Woesik, R., Houk, P., Isechal, A. L., Idechong, J. W., Victor, S., and Golbuu, Y.: Climate change refugia in the sheltered bays of Palau: analogs of future reefs, Ecol. Evol, 2, 2472-2484, 2012.

Yamamoto, S., Kayanne, H., Terai, M., Watanabe, A., Kato, K., Negishi, A., and Nozaki, K.: Threshold of carbonate saturation state determined by $\mathrm{CO}_{2}$ control experiment, Biogeosciences, 9 , 1441-1450, doi:10.5194/bg-9-1441-2012, 2012.

Yao, W. and Byrne, R. H. Simplified seawater alkalinity analysis: use of linear array spectrometers, Deep-Sea Res. Part 1, 45, 1383-1392, 1998.

Yates, K. K. and Halley, R. B.: $\mathrm{CO}_{3}^{2-}$ concentration and $p \mathrm{CO}_{2}$ thresholds for calcification and dissolution on the Molokai reef flat, Hawaii, Biogeosciences, 3, 357-369, doi:10.5194/bg-3-3572006, 2006.

Zepp, R. G., Shank, G. C., Stabenau, E., Patterson, K. W., Cyterski, M., Fisher, W., Bartels, E., and Anderson, S. L.: Spatial and temporal variability of solar ultraviolet exposure of coral assemblages in the Florida Keys: importance of colored dissolved organic matter, Limnol. Oceanogr., 53, 1909-1922, 2008.

Zhang, H. and Byrne, R. H.: Spectrophotometric $\mathrm{pH}$ measurements of surface seawater at in-situ conditions: absorbance and protonation behavior of thymol blue, Mar. Chem., 52, 17-25, 1996. 